\title{
Finansal Gelişme ve Gelir Eşitsizliği: BRICS Ekonomileri İçin Dinamik Heterojen Bir Yaklaşım
}

\author{
Financial Development and Income Inequality: A Dynamic \\ Heterogeneous Approach for BRICS Economies
}

\section{Bahar Baysal Kar - Mikail Kar}

Başvuru Tarihi: 13.03 .2018

Kabul Tarihi: 10.12.2018

\section{Öz}

Bu çalışmada, 1990-2014 dönemi boyunca BRICS ekonomilerinde finansal gelişmenin gelir eşitsizliği üzerindeki rolü araşttrılmaktadır. İşselliği kontrol etmek için finansal gelişme göstergelerine ek olarak, kişi başına düşen reel GSYH'nın büyüme oranı, beşeri sermaye endeksi ve GSYH içerisinde modern sektörün payı araç değişkeni olarak kullanılmıştır ve gelir eşitsizliği gini katsayısı ile ölçülmüştür. Havuzlanmış ortalama grup (PMG) tahmincisine dayalı ampirik sonuçlar, bu yükselen ekonomilerde finansal gelişmenin düşük gelir gruplarına yarar sağlamadığın ileri süren, gelir eşitsizliğini arttırıcı hipotezi desteklemektedir. Diğer bir ifade ile ampirik bulgular finansal gelişmenin gelir eşitsizliğini uzun dönemde arttırdiğını ortaya koymaktadır. Bu çalışmanın politika iması, bu ekonomilerde gelir eşitsizliği ile mücadele etmek için mevcut ekonomi politikalarının finansal erişimin öneminin farkına varması gerektiğidir.

Anahtar Kelimeler: Finansal Gelişme, Gelir Eşitsizliği, BRICS, Heterojen Panel Modelleri

\begin{abstract}
In this paper, the role of financial development on income inequality in BRICS economies is investigated during the period 1990-2014. In addition to financial development indicators, the growth rates of the real GDP per capita, human capital index and modern sector share of GDP as instrument variables are used to control for endogeneity and income inequality is measured by the gini coefficient. The empirical results, based on the pooled-mean group estimator ( $P M G)$, support the inequality-increasing hypothesis, which suggests that financial development does not benefit the low-income groups in these emerging economies. In other words, the empirical findings suggest that financial development increase income inequality in the long run. The policy implication of this paper is that the current economic policies should realize the importance of financial inclusion in order to combat income inequality in these countries.
\end{abstract}

Keywords: Financial Development, Income Inequality, BRICS, Heterogeneous Panel Models

Bahar Baysal Kar, Kırklareli Üniversitesi İIBF, bhrbysl@gmail.com, ORCID: 0000-0003-2335-6299 Mikail Kar, Uludağ Üniversitesi İİF, mklkar@gmail.com, ORCID: 0000-0002-4036-7355 


\section{Giriş}

Finansal gelişmenin gelir dağılımı üzerindeki etkisine iktisat disiplinin ilgisi 1990 'l y ylların başında yoguunlaşmıştır (Greenwood ve Jovanovic, 1990; Galor ve Zeira,1993; Banerjee ve Newman, 1993; Aghion ve Bolton, 1997). Ancak 2008-2009 Global Finans Krizi'nden sonra gerek iktisat disiplininde gerekse kamusal tartışmalarda bu konuya olan ilgi giderek artmıştır. Özellikle finans sektöründe bireysel kazançların, bu bireylerin toplumsal katkılarının çok üzerinde olması, finansal kurumların kayıplarının toplumsallaşması gibi olumsuzluklar göz önüne alındığında finans sektörünün ekonomiye ve daha genel olarak topluma katkısı daha fazla sorgulanmaya başlamıştır (Stiglitz, 2012; Jauch ve Watzka, 2016).

Finansal gelişme-gelir eşitsizliği ilişkisine odaklanan teorik yaklaşımlar çoğunlukla üç farklı hipotez ortaya koymaktadır. Birinci hipotez, finansal gelişmenin düşük gelirli ancak yetenekli bireylerin fikirlerini harekete geçirmek için gerekli mali kaynağı sunarak fırsat eşitliği sağlaması yoluyla gelir eşitsizliği ile mücadelenin bir aracı olabileceğini iddia eder (Galor ve Zeira,1993; Banerjee ve Newman, 1993; Aghion ve Bolton, 1997). İkinci hipotez, kurumsal yapının yetersiz olduğu durumda, finansal piyasa ve kurumlardaki gelişmelerden yalnızca varlıklı kesimin fayda elde edebileceğini savunur (Stiglitz, 2012; Rajan ve Zingales, 2003). Özellikle siyasi desteği de arkasına alan bir kesim, topluma sağladıkları katkının oldukça üzerinde kazanç elde edebilmektedir. Düşük gelirli kesimin sistemden dışlamasının temel nedeni ise, borcun geri ödenmeme riskine karşı teminat niteliğindeki varlıklara veya kişisel bağlantılara sahip olmamalarıdır (Rajan ve Zingales, 2003). Son hipotez, bu iki doğrusal yaklaşımdan farklı olarak finansal gelişmenin gelir eşitsizliğini azaltıcı etkisinin ortaya çıkması için finansal gelişme düzeyinin (Greenwood ve Jovanovic, 1990; Kim ve Lin, 2011) veya kurumsal yapının gelişiminin belirli bir eşik seviyeye ulaşması (Law vd., 2014) gerektiğini vurgular ve doğrusal olmayan bir yaklaşımdır. Bu farklı görüşler finansal gelişme-gelir eşitsizliği arasındaki ilişkiye dair teorik bir uzlaşının olmadığını koymaktadır.

Bu çalışmanın amacı, son otuz yılda küresel ekonomi içerisinde ağırlığı giderek artan ve belirli kurumsal özellikleriyle mukayeseli kapitalizm literatürüne (Nölke ve Claar, 2013; May ve Nölke, 2014; McNally, 2013b) de konu olan beş yükselen piyasa ekonomisinde (Brezilya, Çin, Hindistan, Rusya ve Güney Afrika-BRICS) finansal gelişmenin gelir eşitsizliği üzerindeki doğrudan etkisini analiz ederek bu literatüre katkıda bulunmaktır. Finansal gelişme-gelir eşitsizliği ilişskisine odaklanan literatür genellikle gelişmiş ve gelişmekte olan ekonomileri birlikte ele alarak değerlendirmektedir. Ancak benzer gelişme aşamaları ile gelişmekte olan ülkeler daha homojen bir bütün oluşturabilmektedir. Bu çalışmaya konu olan BRICS ekonomileri de özellikle siyasi ve ekonomik yönleri (rekabetçi üstünlükler, sektör yapılanmaları) ile birbirlerinden farklılaşsalar da (Ünal ve Kayıkçı, 2013), kapitalizmin türleri (varieties of capitalism) literatürü bu ekonomilerde ortak kurumsal özellikleri tasvir etmekte ve örtük biçimde bu özellikleri yüksek oranlı büyümenin kaynağı olarak göstermektedir. Bu çalışmada iktisadi performansın bir göstergesi olarak iktisadi büyüme yerine, gelir eşitsizliği ele alınmış, bu ekonomilerde neredeyse benzer aşamada olan finans sektöründeki gelişmelerin, gelir eşitsizliği üzerindeki etkisi araştırılmıştır. Elde edilen ampirik sonuçlar bir yandan ortak bir uzlaşının olmadı $\breve{g}_{1}$ literatüre katkı sağlarken, diğer yandan gelir eşitsizliğinin azaltılmasına yönelik olarak finans sektörünün nasıl bir reform alanı olduğunu ortaya koymaktadır.

Ampirik analizde heterojen panel veri modellerinden Ortalama Grup Tahmincisi (Mean Group Estimator, MG) ve Havuzlanmış Ortalama Grup Tahmincisinden (Pooled Mean Group Estimator, PMG) yararlanılmış, ancak Pesaran vd., $(1997,1999)$ tarafından önerilen PMG tahmincisi ile elde edilen sonuçlar kullanılmıştır. PMG tahmincisi, ihmal edilmiş değişkenin yol açtığı sapma (omitted variable bias), içsellik (endogeneity) sorunu ve ülke heterojenliği sorunu ile başa çıkabilen, uzun ve kısa dönem katsayılarının ayrı ayrı hesaplanmasına izin veren dirençli bir tahmincidir. Farklı finansal gelişme göstergelerinden yararlanılarak tahmin edilen modellerden elde edilen sonuçlar, söz konusu ülkelerde finansal gelişmenin gelir eşitsizliğini arttırdığını ortaya koymaktadır.

Çalışmanın bundan sonraki kısmında BRICS ekonomilerinin neden analize konu edildiğine ilişkin kısa bir değerlendirme yapılmaktadır. Üçüncü kısım, finansal gelişme-gelir eşitsizliği literatürünün kısa bir özetini sunarken, dördüncü kısım çalışmada kullanılan veri seti ve ampirik stratejiyi tanıtmaktadır. Takip 
eden bölüm tahmin edilen farklı modellerin sonuçlarını ortaya koyarken, son bölüm değerlendirme bölümüdür.

\section{BRICS Ekonomilerinde Finansal Gelişme}

Küresel sistemin geleceği ile ilgili tartışmalarda, iktisadi performansları 2000'li yılların başından itibaren sıklıkla dillendirilen BRICS ekonomileri (O’Neill, 2001), uyguladıkları heterodoks politikalar ve borç yükümlülüklerini finanse etme biçimleri ile (Pradhan vd., 2013) finansallaşmanın olumsuz etkilerinden kaçınarak 2008-2009 küresel krizinden daha az hasarla ve hızla çıkmayı başarmış (Şenses vd., 2013), aynı zamanda "yeni devlet kapitalizmi (refurbished state capitalism) (McNally, 2013a)", "devletin nüfuz ettiği kapitalizm (state-permeated capitalism)" (Nölke ve Claar, 2013) veya "stratejik kapitalizm (Şenses vd., 2013)" gibi isimlerle komünizm sonrası küresel düzenin hakim gücü $\mathrm{ABD}$ tarzı serbest piyasa kapitalizminin yerini sarsmayı başarmışlardır (McNally, 2013b). Serbest piyasa kapitalizminin temel ilkelerini benimseyen ancak stratejik sektörlerde devlet mülkiyetinin ve finans sektöründe farklı düzeylerde devlet kontrolünün varlığını sürdürdüğ̈ ${ }^{1}$ (McNally, 2013b) bu ekonomiler, $\mathrm{ABD}, \mathrm{AB}$ ve Japonya gibi ekonomiler karşında İkinci Dünya Savaşından beri ilk kez küresel büyümenin de öncüsü haline gelmiştir (McNally, 2013a).

Bu büyümeye kaynaklık eden yatırımların finansmanında, aynı zamanda teknolojik gelişmeye de katkısı olan doğrudan yabancı yatırımlar da dikkate çekmekle birlikte, finansal piyasa ve kurumlardaki gelişmelerin katkısı önemlidir. Ancak finansal gelişme bankacılık sektörü ve sermaye piyasası olarak iki kategoride incelenirse, Güney Afrika istisna olmak koşulu ile bu ekonomilerde bankacılık sektörünün hakimiyetinden söz edilmektedir. Sermaye piyasası bu ekonomilerde bankacılık sektörünün gerisinde kalmaktadır. Özellikle Çin, Hindistan ve Brezilya'da firmaların yatırım stratejileri devlet birimlerinin makro

1 Fiyatların belirlenmesi, kıt kaynakların tahsisi ve rekabetçi baskı yaratılması anlamında her ne kadar piyasalara güven tam olsa da, bu ekonomilerde devlet gücünün potansiyel yararlarına ciddi bir inanç vardır ve bu inanç onların yönetim felsefelerinin temelini oluşturmaktadır. Buna göre piyasalar her ne kadar etkin olsa da devlet, doğrudan veya dolaylı olarak iktisadi gelişme üzerinde etkilidir (McNally, 2013a:39-40). ekonomik tercihleri tarafından yönlendirilmektedir. $\mathrm{Bu}$ nedenle devlet büyük meblağlarda krediye bakanlıklar ve özellikle de devlet kontrollü kalkınma bankaları ile aracılık etmektedir (Prasad, 2016; May ve Nölke, 2014; McNally, 2013b; Ang, 2010). Ancak bankacılık sektörünün bu ağırlığına rağmen ( $E k$ Tablo A), sermaye piyasasının gelişimini hızlandırmak ve uluslar arası portföy yatırımlarını cezbetmek için bu ülkeler çeşitli düzenlemeler yapmaktadır (Chittedi, 2009; Prasad, 2016; Shah ve Patnaik, 2011; Ang, 2010; BOR, 2016).

Küresel sermaye piyasalarının yatırımların finanse edilmesinde bankacılık sektörü kadar önemli bir rolü olmamakla birlikte (May ve Nölke, 2014), BRICS ekonomilerinin halihazır ve gelecekte beklenen büyüme performansları dikkate alındığında bu ekonomilerin sermaye piyasasında işlem yapan firmaların piyasa değerlerinin toplamında (stock market capitalization) ve bu ekonomilerin diğer sermaye piyasalarına bağımlılıklarında bir artış olabileceği varsayılmaktadır. BRIC ekonomilerinin 2030 yılında küresel sermaye piyasası kapitalizasyonunun \%41'ini açıklayacağı, Çin'in bu alanda ABD’nin üstünlüğünü ele geçireceği beklenmektedir. Ayrıca bu ekonomiler içerisinde yer alan Güney Afrika’da hem finansal aracılık hem de sermaye piyasaları açısından hızlı bir gelişme gösterdiği gözlemlenebilir (Mensi vd., 2014).

$\mathrm{Bu}$ ekonomilerin dikkat çeken bir diğer özelliği dış şoklara ve krizlere karşı ulusal para birimlerinin ani değer kaybını engellemek için döviz rezervi biriktirme yoluna gitmeleridir. 1990'larda yaşanan krizlerde merkez bankalarının, milli paralarını spekülatif ataklar karşında dolara karşı devalüe etmek zorunda kalmaları, ithalatı karşılayacak rezerv yoksunluğu nedeni ile kısa dönemli borçlanma zorunluluğu ve istenmeyen ticaret serbestleşmesi gibi riskler, bugün bu riskleri ortadan kaldırmak için bu ekonomilerde rezerv biriktirmeyi merkez bankalarının temel önceliği haline gelmiştir (May ve Nölke, 2014). Sürdürdükleri dışa açık ekonomik ilişkiler, sanayileşme ve teknolojik gelişmede gelişmiş toplumlara bağımlılıkları ve kurumsal yapılarında bazı liberal olmayan özellikleri ile bu ekonomiler, küresel rezervlerin \%30'undan daha fazlasına sahiplerdir (McNally, 2013a). Ayrica elde ettikleri bu rezervlerle küresel sistemi de şekillendirme eğilimindedirler. Özellikle Çin yönetimi ABD’nin tek taraflı ekonomik yaptırım kararlarına 
karşı küresel rezerv birimi olan $\mathrm{ABD}$ dolarının yerine çeşitli para birimlerinden oluşan bir döviz sepeti ya da IMF’nin Özel Çekme Hakları benzeri bir sanal para biriminin alması konusunda fikirlerini açıkça dile getirmektedir. Ancak hem finansal piyasalarının gelişmişlik derecesi hem de çeşitli reformlarla politik ve yasal kurumlarının düzenlenme ihtiyacı nedeniyle henüz ABD dolarının üstünlüğü ile yarışamayacă̆1nın farkındadır (Prasad, 2016).

Özellikle modern sektörleri dikkate alındığında bu ortak kurumsal özellikleri ile hem mukayeseli politik ekonomi literatürü, hem de finansal gelişme-iktisadi büyüme ilişkisini inceleyen ampirik çalışmalar (Pradhan vd., 2013), BRICS ekonomilerinde finansal gelişmenin iktisadi büyümeye aracıllk ettiğine işaret etse, gelir dağılımı üzerindeki etkisi konusunda pek bir şey söylememektedir. Oysa bu ekonomilerin en belirgin niteliği artan büyüme ve gelir artışının toplumsal kesimlere aynı derecede yansımaması, gelir dağılımında ciddi adaletsizliklerin yaşanmasıdır. $\mathrm{Bu}$ nedenle bu çalışmada amaç bu ekonomilerde finansal gelişmenin gelir dağılımına etkisini araştırmak ve elde edilen ampirik sonuçlar doğrultusunda çeşitli politika önerileri sunmaktır.

\section{Finansal Gelişme ve Gelir Eşitsizliği: Teorik Yaklaşımlar ve Ampirik Kanıtlar}

Kredi ve varlık piyasalarındaki gelişmelerin, yetenekli ancak düşük gelirli bireyler için hareket alanı yaratarak, fırsat eşitliği sağlaması böylelikle gelir dağılımındaki eşitsizliğe uzun dönemde çözüm olması beklenir (Claessens ve Perotti, 2007). Ancak özellikle 2008 Global Finans Krizi ile artan finansallaşmanın ekonomiye ve genel olarak topluma katkısı daha tartışmalı hale gelmiştir. Özellikle ABD'de gelir eşitsizliğindeki artışın çoğunun finans sektörünün aşırılıklarından kaynaklanması, bu eşitsizliği azaltmaya yönelik reform çabalarının bu alana yoğunlaştırılmasını gündeme taşımıştır (Stiglitz, 2012). Finansal gelişme veya devrim Rajan ve Zingales'in (2003) sıklıkla alıntılanan iki söyleminde dile getirdiği gibi "yalnızca zenginlere mi yarar sağlar?” (Rajan ve Zingales, 2003, s.25) yoksa "iktisadi faaliyetin merkezine sermaye yerine, insanı koyarak", aristokrasi kulübünün kapılarını herkese mi açar?” (Rajan ve Zingales, 2003, s.92)

Bu iki sorunun cevabı bugün literatürde sıklıkla tartışılmaktadır. Ancak ne teorik yaklaşımlarda ne de bu teorik yaklaşımları test eden ampirik çalışmalarda ortak bir uzlaşı yoktur. Bazı modeller finansal gelişmenin iktisadi büyümeyi arttıracağını ve gelir eşitsizliğini azaltacağını ileri sürer. Finansal piyasalardaki ters seçim, ahlaki risk, bilgi ve işlem maliyeti ile ödünç alıcinın teminat gereksinimi gibi sorunlar elinde teminatı bulunmayan veya finansal kurumlarla yakın ilişkileri olmayan düşük gelirli kesim için daha kısıtlayıcıdır ve gelir dağılımında eşitsizliği artırır. Finansal kurum ve piyasaların gelişmesiyle finansal kaynaklara daha yaygın erişim kaynak tahsisinde etkinliği arttırarak, bu eşitsizliğin de azalmasına arac1lık eder (Galor ve Zeira, 1993; Banerjee ve Newman, 1993; Aghion ve Bolton, 1997; Ljungqvist, 1993).

Galor ve Zeira (1993) bireylerin potansiyel beceri ve tercihlerinin aynı ancak miras yoluyla edindikleri servetin farklı olduğu iki sektörlü bir model oluşturmuştur. Kredi piyasası aksaklıklarının da veri kabul edildiği bu ekonomide, bireylerin beşeri sermaye yatırımlarını servetin başlangıç dağılımı belirlemektedir. Eğer servetin başlangıç dağılımı aşırı ölçüde eşitsiz ise çok az insan beşeri sermayeye yatırım yapabilecek, bu durum iktisadi büyümeyi yavaşlatacak ve gelir eşitsizliğini arttıracaktır. Beşeri sermaye yatırımlarının bölünmezliği bu etkileri uzun döneme de taşıyacaktır. Finansal sistem geliştikçe, düşük gelirlilerin beşeri sermaye yatırımının finansmanı için ödünç imkanları artacak, bu durum hem büyümeyi hem de gelir eşitsizliğini azaltacaktır. Banerjee ve Newman (1993) da benzer varsayımlarla benzer bir sonuca ulaşır. Galor ve Zeira’nın (1993) modelinde kredi kısıtı nedeni ile finanse edilemeyen beşeri sermaye yatırımının yerini, Banerjee ve Newman'ın (1993) modelinde bireylerin meslek seçimleri alır. Tek bir malın üretildiği ve bu malın üretim veya yatırım amaçlı kullanıldığı bir ekonomide, Banerjee ve Newman (1993) üç sektörlü bir modelden yararlanmaktadır. Yüksek getirili teknolojiyi kullanan sektörlerdeki fiziksel yatırımlar bölünmez niteliktedir ve yüksek getirili bu yatırım projelerini kredi kısıtı nedeni ile yalnızca varlıklı kesim finanse edebilmektedir. Bu nedenle düşük gelirli bireyler ücretli çalışmayı tercih ederken, zengin olanlar girişimci olmayı seçmektedir. Böylelikle yine servetin başlangıç dağılımı bireylerin meslek seçimlerini etkilerken, kredi kısıtı sermayenin tahsis etkinliğini azaltacak ve yoksul bireylere sermaye akışını engelleyerek gelir eşitsizliğini arttıracaktır. Bu kısitı ortadan kaldıracak olan ise finansal gelişmedir. Aghion ve Balton (1997) sermaye 
piyasası aksaklıklarının varlığını veri kabul ederek, sermaye birikiminin "sızma etkisini (trickle-down effect)" analiz etmektedir. Kredi kısıtı ve ahlaki risk bu piyasanın temel aksaklıkları olarak tanımlanmış, bu kusurlar aynı zamanda gelir eşitsizliğinin de kaynağ1 olarak gösterilmiştir. Buna göre, sermaye birikimi arttıkça bunun neden olduğu iktisadi genişleme süreci sızma etkisi ile yoksul kesimin kredi imkanlarını arttıracak, yoksul kesim yatırım projeleri için ihtiyaç duyduğu fonları elde edebilecektir. Bu modelin diğer modellerden farklı bir yönü gelirin yeniden dağılımı için devlet müdahalesine daha fazla yer açmasıdır.

Finansal gelişmenin, gelir eşitsizliğini azalttığına iddia eden bu modellerin ortak yönü eksik veya aksak sermaye piyasalarının iktisadi gelişme sürecinde gelir eşitsizliğini arttırabileceğini ve finansal piyasalar derinleştikçe ve finansal piyasalara erişim kolaylaştıkça, daha önce beşeri ve fiziksel sermayeye yatırım yapamayanların veya üretken yatırımlar için başlangıç maliyetinden yoksun hane halklarının finansal kaynak sağlama imkanı ortaya çıkacağını vurgulamasıdır. $\mathrm{Bu}$ modellerin ortaya koyduğu sonuçları destekleyen pek çok ampirik çalışmadan bahsedilebilir. Finansal aracılığın gelișiminin gelir eșitsizliği üzerindeki etkisini inceleyen Clarke vd., (2006), aynı zamanda finansal gelişme ile gelir eşitsizliği arasındaki ilişkileri ortaya koyan farklı modelleri test etmektedir. 1960-1995 dönemini kapsayan 83 gelişmiş ve gelişmekte olan ülke için yapilan bu çalışmaya göre finansal aracılığın gelişmesi, gelir eşitsizliğini azaltmaktadır. Beck vd., (2007) 1960-2005 dönemi için 72 ülkeyi kapsayan analizlerinde, finansal gelişme ile gelir eşitsizliği arasında negatif ilişki tespit etmiştir. Claessens ve Perotti (2007) eşitsizlik ve finans arasındaki ilişkiye odaklanan ve daha çok literatür taraması niteliğindeki çalışmalarında, finansal gelişmenin gelir eşitsizliğinin azaltılmasına yardımcı olduğunu ancak finansal serbestleşme reformlarının aksine gelir eşitsizliğini arttırdığını tespit etmiştir. Bittencourt (2006) 1985-1999 dönemi için Brezilya’ya ait zaman serisi verilerini kullanarak hem finansal gelişmenin hem de makroekonomik performansın gelir eşitsizliğine etkisini araştırmıştır. Elde ettiği sonuçlara göre finansal piyasalara ve kredi piyasalarına daha yaygın erişim, gelir eşitsizliğini azaltmaktadır. 1980'ler ve 1990 'lar boyunca finansal piyasalardaki gelişmeler yoksulların refahının artmasına katkıda bulunmuştur. Liang (2006) Çin’de 1986-2000 dönemi için bölgesel verileri kullanarak yaptığı çalışmada finansal gelişmenin gelir eşitsizliğini önemli ölçüde azalttığını tespit etmiştir. Ang (2010) ylllı zaman serisi verilerini kullanarak, 1951-2004 dönemi için Hindistan'da finansal gelișme ve finansal serbestleşmenin gelir dağılımı üzerindeki etkileri incelemiştir. Analizinin sonuçlarına göre, finansal sistemin azgelişmiş olması düşük gelirli kesime, zenginlere nazaran daha fazla zarar vermektedir. Finansal sistemin gelişmesi, gelir eşitsizliğinin azalmasına yardım etmektedir. Ancak finansal serbestleşme reformları düşük gelirlilerin finansal kaynaklara erişimini zorlaştırmakta ve eşitsizliği arttırmaktadır. Batuo vd., (2010) 22 Afrika ülkesi için 1990-2004 dönemini kapsayan verileri ile yaptıkları analizde, finansal gelişme ile gelir eşitsizliği arasında negatif ve doğrusal bir ilişki olduğunu tespit etmiştir. Law vd., (2014) finansal gelişmenin gelir eşitsizliğini azaltıcı etkisinin, finansal sistemin elverişli (sound) bir kurumsal yapı içerisinde yer almasına bağlı olduğunu tespit etmiştir. Zayıf bir kurumsal çevrede, finansal kaynakların etkin dağılımı sağlanmaz ve bu nedenle gelir eşitsizliğinde bir iyileşme olmaz. Hamori ve Hashiquchi (2012) finansal derinleşmenin gelir eşitsizliğini azalttığını ancak iktisadi büyümenin bu etkiyi olumsuz etkilediğini tespit etmiştir.

$\mathrm{Bu}$ yaklaşımların karşı kutbunda yer alan teoriler finansal gelişmenin gelir eşitsizliğine çözüm getirmeyebileceğini ve hatta gelir eşitsizliğini daha da artt1rabileceğini iddia eder. Stiglitze (2012) göre bugün ABD'de gelir eşitsizliğinin artmasının en önemli nedeni finans sektöründeki gelişmelerdir. Finans sektörü, bu sektördeki inovasyonlar ve bu sektördeki piyasa başarısızlıkları ile birlikte siyasal gücü de arkasına alarak toplumun geri kalanı pahasına varlıklı kesime kaynak aktarmanın veya bu kesimin rant arayışının aracı haline gelmiştir. Bu sektörde piyasa başarısızlıkları düzeltilmemiş ve bireysel kazançlar bu bireylerin toplumsal katkılarının oldukça üzerinde kalmaya devam etmiştir. Rajan ve Zingales (2003) göre finansal yapının belirsizlik, ters seçim veya ahlaki risk gibi finansal risklere karşı, ödünç verene geri ödeme garantisi sağlayabilecek yöntem, ödünç alandan teminat alması olduğunun altını çizer ve ödünç almak için teminat gereksinimini nedeniyle, finansal gelişmeden varlıklı kesimin yararlanabileceğini düşünür. Çünkü finansal altyapının az geliştiği yerde borç veren doğal olarak zenginlere yönelir. Zira borcun geri ödenmeme riskine karşı borç verenin endişelerini giderecek 
teminat niteliğindeki varlık veya kişisel bağlantılara yalnızca onlar sahiptir. Bu durumda düşük gelirli ve sağlam bağlantıları olmayan yetenekli insanlar formel finansal sistemden dişlanacak, finansman gereksinimlerini karşılamada kaynakları enformel ilişkiler ile sınırlı kalacaktır ve gelir eşitsizliği böylelikle daha da artacaktır. Hodgson (2015) doğrudan finansal gelişmeye işaret etmese de kapitalist sistemde gelir eşitsizliğini benzer bir mantıkla açıklamaktadır. Ona göre gelir eşitsizliğinin temel nedeni, "para veya teminat gösterilebilen paraya çevrilebilir varlık" olarak tanımladığı sermayedir. Kapitalistler sahip oldukları bu finansal varlıkları borç almak için teminat gösterip, yatırım yapabilmektedir. Sermayenin dinamik doğası yani tekrarlı bir elde etme (extraction) ve yeniden yatırım biçiminde nitelenen sürekli bir süreç varlıklı kesime hep daha fazlasına sahip olma imkanı tanır. Oysa düşük gelirli kesim veya ücretli çalışanlar yaşam boyu kapasitelerini ödünç almada teminat olarak kullanamaz ve işin işçiden ayrılmazlığı diğer üretim faktörlerinin elde etmesi mümkün çeşitli fırsatlardan işgücünü mahrum bırakır. Finansal varlıklar gibi emek faktörünün teminat gösterilememesi, işverenlerin çalışanların becerilerine yatırım yapma teşvikini de azaltması eşitsizliğin bir diğer kaynağıdır. Sistem bilgi ve teknolojiye bağlı hale geldikçe, beceri ve ücret düzeyi düşük bir sınıf ortaya çıkmaktadır. ${ }^{2}$

Özellikle gelişmekte olan ülkeleri kapsayan çalışmaların elde ettiği ampirik bulgular finansal gelişmenin gelir eşitsizliğini arttırdığını ileri süren bu teorik yaklaşımları desteklemektedir. Sehrawat ve Giri (2015) Hindistanın 1982-2012 dönemi için yıllık verilerini kullanarak yaptıkları eşbütünleşme analizinde finansal gelişmenin hem uzun dönemde hem de kısa dönemde gelir eşitsizliğini arttırdığını ortaya koymaktadır. Seven ve Coşkun'un (2016) yükselen piyasa ekonomileri için yaptıkları analize göre finansal gelişme iktisadi büyümeye kaynaklık etmekte ancak gelir eşitsizliğinin azaltılmasında etkili olamamaktadır. Hem finansal aracılığın hem de sermaye piyasasının gelişiminden düşük gelirli kesim yeterince yararlanamamaktadir. Adams ve Klobodu (2016) 1985-2011 döneminde 21 Sahra-altı Afrika ülkesi için yaptıkları analizde finansal gelişmenin eşitsizliğini arttırdığ

2 Hodgson (2015) gelir eşitsizliğini açılamada bu yaklaşımın radikal bir yaklaşımı andırdığını, ancak sermayeyi tanımlama biçiminin Marx ve diğer pek çok ekonomistten farklılaştığını vurgular. sonucuna ulaşmıştır. Ayrıca yolsuzluğun kontrol altına alınması, şeffaflık gibi yönetişim göstergelerine ait katsayıların modelde negatif ve istatistiksel olarak anlamlı olması, gelir eşitsizliği ile mücadelede kurumsal çevrenin önemine işaret etmektedir. Jauch ve Watzkảnın (2016) 1960-2008 dönemi için 138 ülkeyi kapsayan analizleri de finansal gelişmenin gelir eşitsizliğini arttırdığı sonucuna ulaşmıştır.

Bu iki farklı kutupta yer alan modellerin aksine finansal gelişmenin bölüşümsel etkisinin iktisadi gelişme düzeyine bağlı olduğunu ileri süren modellerden de bahsedilebilir. Greenwood ve Jovanoice (1990) göre finansal gelişme ve gelir eşitsizliği arasında yukarıdaki yaklaşımların aksine doğrusal olmayan bir ilişki vardır. Diğer bir ifade ile finansal gelişmenin gelir eşitsizliğini azaltıcı etkisi, finansal gelişmenin belirli bir eşik değere ulaşmasından sonra ortaya çıkmaktadır. Bu eşik değere ulaşana kadar finansal piyasa, düşük gelirlilerin gelir dağılımında nispi konumlarının kötüleşmesine neden olmaktadır. Bu nedenle, finansal gelişme ve gelir eşitsizliği arasındaki ilişki lineer değil, ters U biçimindedir. Kim ve Lin'in (2011) analizi bu sonucu doğrulamaktadır.

\section{Ampirik Analiz}

\section{Veri Seti ve Model}

Veri mevcudiyetine bağlı olarak, kullanılan veri seti 1990-2014 dönemini ve beş yükselen ekonomiyi kapsamaktadır: Çin, Hindistan, Rusya, Brezilya ve Güney Afrika ( $\mathrm{N}=6$ ve $\mathrm{T}=25)$. Küresel anlamda önemini yansıtması bakımından, bu altı ülke 2016 yılı verilerine göre dünya GSYH'sının neredeyse dörtte birini ve dünya nüfusunun ise yaklaşık yarısını oluşturmaktadir. $^{3}$

Finansal gelişmenin gelir eşitsizliği üzerindeki etkisini test etmek için tahmin edilen model aşağıdaki gibidir:

$$
\begin{aligned}
\operatorname{GINI}_{i t}= & \alpha_{i}+\beta_{1} \operatorname{FINDEV}_{i t}+\beta_{2} P G D P G_{i t}+ \\
& \beta_{3} \text { HUMANCAP }_{i t}+\beta_{4} \text { MODERN }_{i t}+\varepsilon_{i t}
\end{aligned}
$$

\footnotetext{
32016 yılında dünya GSYH’si içerisinde bu ülkelerin payı $\% 23.13$ ve dünya nüfusu içerisinde $\% 44.30$ 'dur (Dünya Bankas1, 2017).
} 
(1) no’lu eşitlikte, GINI, gelir dağılımındaki eşitsizliği ölçen gini katsayısı, FINDEV, finansal gelişme göstergesini, PGDPG, kişi başına düşen reel GSYH büyüme oranını, HUMANCAP, beşeri sermaye endeksini, MODERN, sanayi ve hizmetler sektörü katma değerinin GSYH içerisindeki payını temsil etmektedir.

Gelir eşitsizliği verileri (GINI), "Standartlaştırılmış Dünya Gelir Eşitsizliği (The Standardized World Income Inequality SWIID)" veri tabanından elde edilmiştir (Solt, 2016). 0 ile 100 arasında ölçeklendirilen bu verilerin sıfırdan itibaren artan değerler alması gelir eşitsizliğinin artması anlamına gelmektedir. Finansal gelişme göstergesi olarak üç farklı değişken kullanılmıştır: Özel sektöre bankalar tarafından sağlanan kredilerin GSYH'ya oram (FINDEV $\left.V_{1}\right)$, mevduat bankaları varliklarinin GSYH'ya oranı $\left(F I N D E V_{2}\right)$ ve finans sektörünün büyüklüğünün bir ölçüsü olan " $f i$ nansal sistemin likit yükümlülüklerinin GSYH'ya ora$n \iota$ (FINDEV $\left.{ }_{3}\right)$ ". Bu göstergeler Dünya Bankası tarafından hazırlanan "Finansal Gelişme ve Yapı (Financial Development and Structure)" veri tabanının en son güncellenen 2017 versiyonundan elde edilmiştir.

$\mathrm{Bu}$ finansal gelişme göstergeleri, bankacıllk sektörünün veya finansal aracılığın gelişimini ölçmektedir. Temel olarak bankacılık sektörüne odaklanılmasının nedeni örneklemi oluşturan BRICS ekonomilerinde, bankacılık sektörünün devam eden hakimiyetidir. Banka kredileri bu ekonomilerde yatırımların temel finansman kaynağıdır (Prasad, 2016; May ve Nölke, 2014; McNally, 2013b; Ang, 2010). Ayrica sermaye piyasasına ait göstergelerde, bazı ülkeler için bazı yıllara ait veriler eksiktir.

$\mathrm{Bu}$ finansal gelişme göstergelerine ek olarak, içselliği kontrol etmek için kontrol değişkenleri de modele dahil edilmiştir. (1) no’lu eşitlikte de görülen bu değişkenlerden, PGDPG, kişi başına düşen reel GSYH büyüme oranı, HUMANCAP, beşeri sermaye endeksi ve MODERN, sanayi ve hizmet sektörü katma değerinin toplam GSYH içindeki payıdır ve bu değişkenler gelir eşitsizliği literatüründe sıklıkla kullanılan standart değişkenlerdir. Kişi başına düşen GSYH büyüme oranı, örneklem dönemi boyunca kişi başına düşen reel gelirin büyüme oranına eşittir ve finansal gelişmenin, iktisadi büyüme yoluyla gelir eşitsizliğini etkileyebilmesi nedeni ile modele dahil edilmiştir (Beck vd., 2007; Ang, 2010). Beşeri sermaye endeksi, eğitim süresi ve eğitimden sağlanan getirilere dayalı olarak hesaplanmıştır ve Penn Dünya Tablosu veri tabanından (Penn World Table) elde edilmiştir. Beşeri sermayedeki artışın, gelir artışı yoluyla eşitsizliği azaltması beklenir (Galor ve Zeira, 1993; Schultz, 1961). Tarımdan sanayi ve hizmet sektörüne doğru bir dönüşümün ya da ekonomide sanayi ve hizmet sektörünün nispi ağırlığında bir artışın gelir dağılımında eşitsizliği arttırdığını ileri süren Kuznets'in (1955) hipotezini test etmek için sanayi ve hizmet sektöründe yaratılan katma değerin GSYH içerisindeki payı da kontrol değişkeni olarak modele dahil edilmiştir. Kişi başına düşen reel GSYH büyüme oranı ve beşeri sermaye endeksi verileri dışındaki tüm değişkenlerin doğal logaritması alınmıştır.

\begin{tabular}{lccccc}
\multicolumn{1}{l}{ Tablo 1. Özet İstatistikler } & \multicolumn{5}{l}{} \\
\hline Değişkenler & Veri Kaynă̆1 & Ortalama & Standart Sapma & Minimum & Maksimum \\
\hline GINI & SWIID & 1.65 & 0.07 & 1.37 & 1.77 \\
FINDEV $_{1}$ & WDI & 1.63 & 0.29 & 0.75 & 2.11 \\
FINDEV $_{2}$ & WDI & 1.75 & 0.23 & 1.01 & 2.15 \\
FINDEV $_{3}$ & WDI & 1.72 & 0.25 & 1.05 & 2.25 \\
PGDPG & WDI & 3.37 & 4.91 & -14.56 & 13.63 \\
HUMANCAP & Penn World Table & 2.29 & 0.49 & 1.48 & 3.35 \\
MODERN & WDI & 1.94 & 0.04 & 1.84 & 1.98
\end{tabular}

Modelde kullanılan bu değişkenlere ait özet istatistikler Tablo 1'de ve Ek Tablo B'de sunulmuştur. Örneklemi oluşturan BRICS ekonomileri içerisinde en yüksek eşitsizlik Güney Afrika’ya aittir ve gini katsayısının 1990-2014 dönemi için ortalaması bu ülkede 57.12'dir. Güney Afrika’yı sırasıyla Brezilya (49.34), 
Hindistan (45.36), Çin (44.90) ve Rusya (36.50) takip etmektedir ${ }^{4}$. BRICS ekonomilerinde yüksek oranlı büyümeye rağmen bu gelir eşitsizliği, eşitsizlikle büyüme (growth with inequality) (Feng, 2011) veya artan eşitsizlik pahasına büyüme olarak adlandırılmaktadır.

Gelir eşitsizliği verilerinin yanı sıra diğer göstergeler finansal sistemin, özellikle de finansal aracılığın belli bir gelişmişlik düzeyine ulaştığını göstermektedir. Ayrıca modern sektörün yani sanayi ve hizmetler sektörünün bu ülkelerde iktisadi faaliyetin neredeyse büyük bölümünü oluşturduğu görülmektedir.

\section{Ekonometrik Metodoloji}

Finansal gelişme-gelir eşitsizliği ilişkisi üç adımda analiz edilmiştir. İlk olarak panel birim kök testlerinden yararlanılarak, analizde kullanılan serilerin durağan olup olmadıkları araştırılmıştır. Panel veri

4 Bu ekonomilerde gelir eşitsizliği Güney Afrika'da çoğunlukla 1910'dan itibaren beyazların hakimiyetini güçlendiren ve 1994’e kadar süren ayrımcı politika ve kurumlar ile ilişkilendirilmektedir. 1913'te çıkarılan bir yasa ile beyazlara tarım arazilerinin \%93’ü tahsis edilmiş, nüfusun \% 60'ını oluşturan siyahlar ise yalnızca \% 7'sine sahip olabilmiştir. Siyahların mülk sahibi olma, iş kurma ve sözleşme yapma hakları ellerinden alınmıştır. Ayrıca 1920'lerden itibaren nitelik gerektiren işlerde çalışmaları yasaklanmış, 1948'den itibaren güçlenen apartheid devlet başta eğitim olmak üzere çeşitli politika alanlarında ayrımcı uygulamalarını yoğunlaştırmış, tüm bu uygulamalar gelir eşitsizliğinin artmasına neden olmuştur (Acemoğlu ve Robinson, 2015). Çin'de ülkenin farklı coğrafi bölgeleri arasında gelir farklılıkları, Hindistan'da farklı toplum kesimleri arasında ayrışmalar gibi nedenlerle arttığı ileri sürülen gelir eşitsizliğinin, Rusya'da Çin ve diğer komünizm sonrasi toplumlara nazaran daha ciddi boyutlarda olduğu ancak eșitsizliğin olması gerekenin altında hesaplandığına işaret edilmektedir. Bu ciddi artışın ardındaki temel neden olarak ise Rusya'nın piyasa ekonomisine geçiş stratejisi, bu dönemde uygulanan politikalar, oluşturulan kurumlar sonucu özel mülkiyetin belirli bir kesimin elinde yoğunlaşması olarak gösterilmektedir (Novokmet vd., 2017). Gelir eşitsizliği trendinin, örneklemde yer alan ülkeler içerisinde tersine döndüğü gözlemlenen tek istisna Brezilya'dır ve yeni kalkınmacı olarak nitelenen kapitalizm modeli ile serbest piyasa ekonomisini patronaja değil, liyakata dayalı devlet müdahalesi teknikleri, profesyonel bir ekonomi bürokrasisi modeli ve kapsamlı sosyal politikalarla harmanlayan bir denge yakalaması (Wiltse, 2013) gelir eşitsizliğindeki bu azalışın nedeni olarak gösterilmektedir. serilerinin durağan olmaması durumunda sahte regresyon sorunu ortaya çıkabilmektedir. $\mathrm{Bu}$ nedenle eğer seriler durağan değilse fark alma işlemi ile seriler durağan hale getirilir. İkinci aşamada, birim kök testi sonuçlarına göre, bağımlı ve bağımsız değişkenlerin birim kök içermesi durumunda, değişkenler arasında uzun dönemde eşbütünleşme olup olmadığ 1 araşt1rılır. Son aşamada, eğer panel eş bütünleşme testleri sonucunda değişkenler arasında uzun dönemli ilişki bulunmuşsa, çeşitli tahmin metotları ile kısa ve uzun dönem katsayıları tahmin edilerek eşbütünleşme analizi tamamlanır. Bu çalışmada hem kısa hem de uzun dönem parametrelerinin tahmin edilmesine olanak sağlayan ortalama grup (MG), havuzlanmış ortalama grup (PMG) tahmincilerinden yararlanılmıştır.

\section{Panel Birim Kök Testleri}

Analizde kullanılan serilerin durağanlığını sınamak için, birinci nesil panel birim kök testlerinden Im vd., (IPS, 2003), Fisher ADF (Maddala ve Wu, 1999) ve Breitung (2001) birim kök testi kullanılmıştır. Birinci nesil birim kök testlerinin tercih edilmesinin nedeni, modelde kullanılan değişkenler arasında yatay kesit bağımlılığının bulunmaması ${ }^{5}$ ve panel veri setinde bazı gözlemlerin eksik olmasıdır.

İlk iki test birinci nesil, ikinci grup testlerdendir. Birinci grup birim kök testlerinden farklı olarak, bu iki test de her bir yatay kesit biriminin kendi otokorelasyon katsayısına sahip olmasina izin vermektedir.

IPS testi, sabit terimler ile eğim katsayılarının heterojenliğini ve ardışık bağımlılığı (serial corelation) dikkate almaktadır. Y, ilgili değişken olmak üzere aşağıdaki modelden hareket edilmektedir:

$\Delta Y_{i, t}=\alpha_{i}+\rho_{i} Y_{i, t-1}+\sum_{s=1}^{p_{i}} \beta_{i, z} \Delta Y_{i, t-z}+\lambda_{i} t+\varepsilon_{i, t}$

2 no'lu eşitlikte, $\alpha_{i}$ heterojen sabit terim, $\lambda_{i} t$ zaman trendi, $\rho$, ADF regresyonu için seçilen gecikme sayıs1dır ve $\varepsilon_{i, t} \sim N I\left(0, \sigma_{i}^{2}\right)$. IPS birim kök testi hipotezleri ise şöyledir:

5 Modelde kullanılan değișkenler arasında yatay kesit bağımlılığının olup olmadığı, Pesaran $\mathrm{CD}_{\mathrm{LM}}$ testi kullanılarak araştırılmıştır. Pesaran yatay kesit bağımsızlık testi sonuçları Ek Tablo C'de sunulmuştur. 


$$
\begin{aligned}
& H_{0}: \rho_{i}=0 \text { ( tüm i’ler için) } \\
& H_{1}:\left\{\begin{array}{l}
\rho_{i}<0 \text { tüm } i=1,2, \ldots, N \\
\rho_{i}=0 \text { tüm } i=N_{1}+1, \ldots, N
\end{array}\right.
\end{aligned}
$$

$H_{0}$ hipotezini test etmek için bireysel test istatistiği $t_{p}$, ve tüm i'ler için $\rho_{i}=0$ olmak üzere, IPS testi bireysel ADF birim kök testi istatistiklerinin ortalamasıdır (Baltagi, 2005).

Maddala ve Wu (1999) tarafından geliștirilen ADF Fisher birim kök testi, her bir yatay kesit birimi, $i$, için yapılan birim kök test istatistiklerinin p (olasılık) değerlerini kullanmaktadır. IPS testinde olduğu gibi Fisher testleri de heterojen katsayıları dikkate alır. $\mathrm{Bu}$ test aşağıdaki gibi formüle edilebilir (Baltagi, 2005):

$$
P=-2 \sum_{i=1}^{n} \ln p_{i}
$$

(Tüm birimler birim kök içermektedir)

(Bazı birimler durağandır)

3 no'lu eşitlikle formüle edilen bu test $2 \mathrm{~N}$ serbestlik derecesi ile asimptotik olarak ki-kare dağılımına sahiptir. Hipotez testleri ise aşağıdaki gibidir:

$H_{0}$ : Tüm birimler birim kök içermektedir.

$H_{1}$ : En az bir birim durağandır.

Breitung (2000) birim kök testi, birinci nesil, birinci grup testlerden biridir. Bu nedenle tüm yatay kesit birimlerine ait serilerin ortak bir otokorelasyon katsayısına sahip olduğu varsayılır. Zaman $(\mathrm{T})$ ve kesit $(\mathrm{N})$ boyutu dar olan panel veri serilerinde bile iyi sonuç-

\begin{tabular}{|c|c|c|c|c|c|c|}
\hline & \multicolumn{2}{|c|}{ IPS } & \multicolumn{2}{|c|}{ Fisher ADF } & \multicolumn{2}{|c|}{ Breitung } \\
\hline & t istat. $\mathrm{I}(0)$ & t istat. $\mathrm{I}(1)$ & t istat. $\mathrm{I}(0)$ & t istat. I(1) & t istat. $\mathrm{I}(0)$ & t istat. $\mathrm{I}(1)$ \\
\hline GINI & -1.15777 & -2.86896 & 15.5826 & 23.4323 & -0.27314 & -1.14425 \\
\hline$\overline{F I N D E V}_{1}$ & -1.36759 & $-4.37206^{\prime \prime}$ & 12.3787 & $34.8348^{\prime \prime \prime}$ & -1.28446 & $-3.23205^{\mathrm{mm}}$ \\
\hline$\overline{\text { FINDEV }_{2}}$ & -1.15433 & $-7.46182^{*}$ & 10.6426 & $50.9476^{* \pi}$ & -0.68089 & $-2.53265^{* 2 \pi m}$ \\
\hline $\mathrm{FINDEV}_{3}$ & -1.13478 & $-6.98611^{\prime \prime \prime}$ & 10.4184 & $45.7512 \%$ & -0.62258 & $-5.47378^{n+m}$ \\
\hline PGDPG & 0.00610 & -3.96896 & 5.79341 & 32.2289 & -0.59401 & -3.06080 \\
\hline HUMANCAP. & -0.07243 & -1.36524 & 8.29911 & 18.1539 & 0.10875 & -1.78950 \\
\hline MODERN & -0.28977 & -8.45544 & $18.2752^{\circ}$ & $68.8148^{*}$ & -1.20597 & -5.53206 \\
\hline
\end{tabular}
lar verebilmektedir.

Tablo 2. Panel Birim Kök Testleri

***,**,* s1rasıly $\% 1, \% 5$ ve $\% 10$ anlamlllık düzeyini göstermektedir.

Tablo 2'de panel birim kök testlerinin sonuçları görülmektedir. Tüm modellerde sabitli ve trendli bir modelden yararlanılmıştır. Her üç testin ortak sonucu değişkenlerin düzeyde durağan olmadığıdır. Serilerin birim kök içerdiği saptandığından, birinci farklarının durağanlığı da araştırılmıştır. Analizde kullanılan serilerin birinci farklarına birim kök testi yapıldığında elde edilen netice, serilerin birinci farklarının durağan olduğudur. Bu serilerden GINI için, Breitung testi serinin birinci farkının durağan olmadığına işaret etse de, IPS ve Fisher ADF testinde serinin birinci farkının durağan olduğu tespit edildiğinden, GINI serisi I(1) kabul edilmiştir.

\section{Panel Eşbütünleşme Testleri}

Birim kök testlerinin sonuçları, serilerin birinci farklarının durağan olduğuna işaret ettiğinden, bundan sonraki aşama, panel eşbütünleşme testleri ile değişkenler arasında uzun dönemli ilişkinin varlığının tespit edilmesidir. Bu çalışmada Pedroni (1999, 2004), Kao (1999) ve Johansen-Fisher eşbütünleşme testleri kullanılarak, uzun dönemli ilişkilerin varlığı araştırılmıştır.

Pedroni (1999), durağan olmayan panellerde "eşbütünleşme yoktur" biçimindeki $\mathrm{H}_{\mathrm{O}}$ hipotezini test etmek için dördü grup içi ve üçü gruplar arası olmak üzere yedi farklı test önermektedir. Pedroni'nin (1999, s. 656) bu testler için ortaya koyduğu eşbütünleşme denklemi aşağıdaki gibidir: 


$$
Y_{i t}=\alpha_{i}+\delta_{i} t+\beta_{1 i} X_{1 i, t}+\beta_{2 i} X_{2 i, t} \ldots+\beta_{M i} X_{M i, t}+\varepsilon_{i, t}
$$

4 no'lu eşitlikte $\mathrm{t}=1 \ldots \mathrm{T}, \mathrm{i}=1 \ldots \mathrm{N}$ ve $\mathrm{m}=1 \ldots \mathrm{M}$ olmak üzere $\mathrm{T}$ zaman boyutunu, $\mathrm{N}$ yatay kesit boyutunu ve $\mathrm{M}$ regresyondaki değişken sayısını temsil etmektedir. $\mathrm{N}$ tane yatay kesit birimi olduğuna göre, $\mathrm{N}$ tane farklı eşitlik vardır. Eğim katsayılarının, $\beta_{1 i}, \beta_{2 i}, \ldots \beta_{M i}$, panelin farklı birimleri arasında farklılaşmasına izin verilmektedir. $\alpha_{i}$, birimler arasında farklılaşmasına izin verilen birimlere özgü sabit terim veya sabit etkiler parametresi, , deterministik zaman trendi ve $\varepsilon_{i, t}$ artıkları temsil etmektedir. Modelin kalıntıları,

$\hat{e}_{i, t}=\gamma \hat{e}_{i, t-1}+\hat{u}_{i, t}$

olmak üzere, otoregresif katsayı için ortak bir değerin tahmin edildiği $(\gamma i=\gamma)$ grup içi testler için hipotezler şöyledir:

$\mathrm{H}_{0}=\gamma_{\mathrm{i}}=1 \quad$ (tüm i’ler için)
$\mathrm{H}_{0}=\gamma_{\mathrm{i}}=\gamma<1 \quad$ (tüm i’ler için)

Gruplar arası istatistiklerde ise otoregresif katsayı $(\gamma)$ için alternatif hipotezde ortak bir değer varsayımı yoktur:

$$
\begin{array}{ll}
\mathrm{H}_{0}=\gamma_{\mathrm{i}}=1 & \text { (tüm i'ler için) } \\
\mathrm{H}_{0}=\gamma_{\mathrm{i}}<1 & \text { (tüm i'ler için) }
\end{array}
$$

$\mathrm{Bu}$ çalışmada değişkenler arasındaki uzun dönemli ilişki olup olmadığı, sabit ve trendin olmadığı varsayımı ile Schwarz kriteri ve uzun dönem varyansını bulmak için Newey-West tahmincisi kullanılarak modellenmiştir. Farklı finansal gelişme göstergeleri kullanılarak tahmin edilen farklı modeller için panel eşbütünleşme testlerinin sonuçları Tablo 3, Tablo 4 ve

\begin{tabular}{|c|c|c|c|c|}
\hline \multicolumn{5}{|c|}{ Pedroni Panel Eşbütünleşme Testi } \\
\hline \multicolumn{4}{|c|}{ Grup içi (Within Dimension) } & $t$ istatistiği \\
\hline \multicolumn{4}{|c|}{ Panel v-istatistiği } & 0.787941 \\
\hline \multicolumn{4}{|c|}{ Panel rho-istatistiği } & -0.156546 \\
\hline \multicolumn{4}{|c|}{ Panel PP-istatistiği } & -2.249172 \\
\hline \multicolumn{4}{|c|}{ Panel ADF-istatistiği } & $-2.714091^{\prime \prime}$ \\
\hline \multicolumn{4}{|c|}{ Gruplar Arast(Between Dimension) } & t istatistiği \\
\hline \multicolumn{4}{|c|}{ Grup rho istatistiği } & 0.618635 \\
\hline \multicolumn{4}{|c|}{ Grup PP istatistiği } & $-1.664538^{n \pi}$ \\
\hline \multicolumn{4}{|c|}{ Grup ADF istatistiği } & $-2.863958^{n \pi n}$ \\
\hline \multicolumn{5}{|c|}{ Kao Panel Eşbütünleşme Testi } \\
\hline & & \multicolumn{2}{|c|}{$\begin{array}{l}\text { tistatistiği } \\
-1.848083 \\
\end{array}$} & Olasılık Değeri \\
\hline \multicolumn{2}{|l|}{ ADF } & \multicolumn{2}{|c|}{-1.848083} & $\mathbf{0 . 0 3 2 3}$ \\
\hline \multicolumn{5}{|c|}{ Johansen Fisher Panel Eșbüttünleșme Testi } \\
\hline $\begin{array}{l}\text { Eşbütünleşme } \\
\text { Sayısı }\end{array}$ & $\begin{array}{l}\text { Fisher istat. } \\
\text { (Trace Test) }\end{array}$ & Olasılık Değeri & $\begin{array}{c}\text { Fisher istat. } \\
\text { Maks. Eigen Test }\end{array}$ & Olasılık Değeri \\
\hline None & 150.5 & 0.0000 & 63.06 & 0.0000 \\
\hline At most 1 & $101.0^{n+m}$ & 0.0000 & $54.76^{* 1+1}$ & 0.0000 \\
\hline At most 2 & $56.47^{* \pi *}$ & 0.0000 & $34.12^{3 * \pi}$ & 0.0002 \\
\hline At most 3 & $34.19^{n+m}$ & 0.0002 & $22.00^{* m+4}$ & 0.0151 \\
\hline At most 4 & 31.04 & 0.0006 & 31.04 & 0.0006 \\
\hline
\end{tabular}
Tablo 5'te görülmektedir.

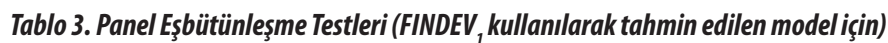

***,***** sırasıyla $\% 1, \% 5 \mathrm{ve} \% 10$ anlamlılık düzeyini göstermektedir.

Tablo 3’teki panel eşbütünleşme testi sonuçlarına göre, grup içi istatistiklerden, panel v ve panel rho istatistiği anlamlı değildir ve bu nedenle $\mathrm{H}_{0}$ hipote- zi reddedilememektedir. Ancak panel PP ve panel $\mathrm{ADF}$ istatistikleri, \%1 düzeyinde istatistiksel olarak anlamlıdır ve $\mathrm{H}_{0}$ hipotezi reddedilmektedir. Yani bu 
iki test istatistiği, ilgili değişkenler arasında uzun dönemli ilişki olduğunu ortaya koymaktadır. Gruplar arası istatistiklerden grup rho istatistiği dışında grup $\mathrm{PP}$ ve grup $\mathrm{ADF}$ istatistiği sırasıyla $\% 5$ ve $\% 1$ düzeyinde anlamlıdır. Bu yedi testten dördü $\mathrm{H}_{0}$ hipotezini reddettiğinden, değişkenler arasında eşbütünleşme ilişkisi olduğu kabul edilmiştir. Tablo 4 ve Tablo 5 'te farklı finansal gelişme göstergeleri kullanılarak tahmin edilen panel eşbütünleşme testleri de benzer sonuçlara işaret etmektedir.

İkinci olarak uygulanan Kao (1999) panel eşbütünleşme testinde, bireysel sabitin olduğu, gecikme uzunlu- ğunun seçiminde Schwarz kriterinin ve uzun dönem veryansının belirlemesinde Newey-West tahmincilerinin kullanıldı $\breve{g}_{1}$ bir model tahmin edilmiștir. Tablo 3’te Kao eșbütünleşme test istatistiği \%5 düzeyinde istatistiksel olarak anlamlıdır. Bu değişkenler arasında uzun dönemli ilişki olduğunu göstermektedir. Farklı finansal gelişme göstergeleri için tahmin edilen Tablo 4 ve Tablo 5 'teki modellerde Kao panel eşbütünleşme testleri, $\mathrm{H}_{0}$ hipotezini $\% 1$ anlamlılık düzeyi ile reddetmektedir. Yani seriler arasında eşbütünleşme vardir ve $\mathrm{H}_{1}$ hipotezi kabul edilmektedir.

Tablo 4. Panel Eşbütünleşme Testleri (FINDEV ${ }_{2}$ kullanılarak tahmin edilen model için)

\begin{tabular}{|c|c|c|c|c|}
\hline \multicolumn{5}{|c|}{$G_{I N I_{i t}}=\alpha_{i}+\beta_{1} F I N D E V 2_{i t}+\beta_{2} G D P G_{i t}+\beta_{3} H_{U M A N C A P_{i t}}+\beta_{4} M O D E R N_{i t}+\varepsilon_{i t}$} \\
\hline \multicolumn{5}{|c|}{ Pedroni Panel Eşbütünleşme Testi } \\
\hline \multicolumn{4}{|c|}{ Grup içi (Within Dimension) } & t istatistiği \\
\hline \multicolumn{4}{|c|}{ Panel v-istatistiği } & -1.049054 \\
\hline \multicolumn{4}{|c|}{ Panel rho-istatistiği } & -0.251371 \\
\hline \multicolumn{4}{|c|}{ Panel PP-istatistiği } & -2.478288 \\
\hline \multicolumn{4}{|c|}{ Panel ADF- istatistiği } & $-2.972776 "$ \\
\hline \multicolumn{4}{|c|}{ Gruplar Arası(Between Dimension) } & t istatistiği \\
\hline \multicolumn{4}{|c|}{ Grup rho istatistiği } & 1.077311 \\
\hline \multicolumn{4}{|c|}{ Grup PP istatistiği } & $-1.749244^{37 \%}$ \\
\hline \multicolumn{4}{|c|}{ Grup ADF istatistiği } & $-3.422779^{2 * 2 * \pi}$ \\
\hline \multicolumn{5}{|c|}{ Kao Panel Eşbütünleşme Testi } \\
\hline \multicolumn{4}{|c|}{ t istatistiğ $i$} & Olasılık Değeri \\
\hline \multicolumn{2}{|l|}{$\mathrm{ADF}$} & \multicolumn{2}{|c|}{-2.516848} & 0.0059 \\
\hline \multicolumn{5}{|c|}{ Johansen Fisher Panel Eşbütünleşme Testi } \\
\hline $\begin{array}{l}\text { Eşbütünleşme } \\
\text { Sayısı }\end{array}$ & $\begin{array}{l}\text { Fisher istat. } \\
\text { (Trace Test) }\end{array}$ & Olasılık Değeri & $\begin{array}{c}\text { Fisher istat. } \\
\text { Maks. Eigen Test }\end{array}$ & Olasılık Değeri \\
\hline None & 169.1 & 0.0000 & 94.70 & 0.0000 \\
\hline At most 1 & $93.96^{* \pi * \pi}$ & 0.0000 & $64.74^{* * *}$ & 0.0000 \\
\hline At most 2 & $40.26^{*+1 * \pi}$ & 0.0000 & $29.32^{* m}$ & 0.0011 \\
\hline At most 3 & $21.42^{* * * *}$ & 0.0184 & 13.57 & 0.1934 \\
\hline At most 4 & $25.42^{\prime \prime \prime \prime}$ & 0.0046 & $25.42^{\prime \prime}$ & 0.0046 \\
\hline
\end{tabular}

***,**,* sırasılyla $\% 1, \% 5$ ve $\% 10$ anlamlılık düzeyini göstermektedir.

Son olarak Johansen-Fisher eşbütünleşme testi sonuçları da, sabit ve trendli bir modelden hareketle ve bir gecikme ile değişkenler arasında uzun dönemli ilişkiye işaret etmektedir. Her üç modelde de, hem iz (trace) hem de Maksimum-eigen istatistiklerinin olasılık değerlerine göre boş hipotez çoğunlukla reddedilmiş, gelir eșitsizliği ile finansal gelişme ve diğer kontrol değişkenleri arasında uzun dönemli bir ilişkiye işaret eden alternatif hipotez kabul edilmiştir. 


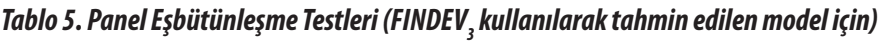
GINI $_{i t}=\alpha_{i}+\beta_{1}$ FINDEV3 $_{i t}+\beta_{2} G D P G_{i t}+\beta_{3}$ HUMANCAP $_{i t}+\beta_{4}$ MODERN $_{i t}+\varepsilon_{i t}$

\begin{tabular}{|c|c|c|c|c|}
\hline \multicolumn{5}{|c|}{ Pedroni Panel Eşbütünleşme Testi } \\
\hline \multicolumn{4}{|c|}{ Grup içi (Within Dimension) } & $t$ istatistiği \\
\hline \multicolumn{4}{|c|}{ Panel v-istatistiği } & -0.158700 \\
\hline \multicolumn{4}{|l|}{ Panel rho-istatistiği } & -0.254019 \\
\hline \multicolumn{4}{|l|}{ Panel PP-istatistiği } & -1.705284 \\
\hline \multicolumn{4}{|c|}{ Panel ADF- istatistiği } & $-3.856101 "$ \\
\hline \multicolumn{4}{|c|}{ Gruplar Arası(Between Dimension) } & $t$ istatistiği \\
\hline \multicolumn{4}{|c|}{ Grup rho istatistiği } & 1.323679 \\
\hline \multicolumn{4}{|l|}{ Grup PP istatistiği } & $-1.853715^{2 * 3}$ \\
\hline \multicolumn{4}{|l|}{ Grup ADF istatistiği } & $-4.375127^{2,7 x \pi}$ \\
\hline \multicolumn{5}{|c|}{ Kao Panel Eşbütünleşme Testi } \\
\hline & & \multicolumn{2}{|c|}{ t istatistiği } & Olasılık Değeri \\
\hline $\mathrm{ADF}$ & & \multicolumn{2}{|c|}{-2.392586} & 0.0084 \\
\hline \multicolumn{5}{|c|}{ Johansen Fisher Panel Eşbütünleşme Testi } \\
\hline Eşbütünleşme Sayısı & $\begin{array}{l}\text { Fisher istat. } \\
\text { (Trace Test) }\end{array}$ & Olasılık Değeri & $\begin{array}{l}\text { Fisher istat. } \\
\text { Maks. Eigen Test }\end{array}$ & Olasılık Değeri \\
\hline None & $136.2^{\prime \prime}$ & 0.0000 & 72.11 & 0.0000 \\
\hline At most 1 & $78.48^{* m+n}$ & 0.0000 & $54.69^{n+m}$ & 0.0000 \\
\hline At most 2 & $33.95^{* * * \pi}$ & 0.0000 & $22.82^{* * *}$ & 0.0114 \\
\hline At most 3 & $20.32^{3 *}$ & 0.0264 & 15.15 & 0.1269 \\
\hline At most 4 & 21.13 & 0.0202 & 21.13 & 0.0202 \\
\hline
\end{tabular}

***,**** sirasıly $\% 1, \% 5$ ve $\% 10$ anlamlılık düzeyini göstermektedir.

\section{Kısa ve Uzun Dönemli İlişkilerin Tahmini}

Analizin üçüncü aşaması kısa ve uzun dönemli ilişkilerin tahminidir. Bu çalışma, beş yükselen ekonominin $(\mathrm{N}=5), 1990-2014$ dönemine ait yıllık $(\mathrm{T}=25)$ verileri kullanılarak yapılmıştır. Zaman dönemi veri kısıtı nedeni ile her bir ülke için ayrı ayrı model tahmin etmek için yeterli değildir. Bu nedenle veriler havuzlanmıştır. Ayrıca örneklemin zaman boyutu, mikro panellere nazaran uzun olduğundan $(\mathrm{T}>20)$ eğim parametrelerinin farklı tahmin edilmesi olası hale gelmiştir. Temelde odaklanılan, değişkenler arasındaki uzun dönem ilişkisi olmasına rağmen, uzun ve kısa dönem etkilerinin birbirlerinden ayrilması çalışmanın istenir özelliklerindendir. Bu nedenle çalışmada eğim katsayılarının yatay kesit birimleri için farklı olduğu, durağan olmama durumunu da dikkate alan dinamik panelleri tahmin etmek için önerilen dinamik heterojen panel veri modellerinden biri olan havuzlanmış ortalama grup tahmincisinden (pooled mean group estimator-PMG) (Pesaran vd., 1997) yararlanılmıştır.

PMG tahmincisi, $\mathrm{N}$ tane farklı regresyon tahmin ederek veya çalışma bağlamında her bir ülke için oluşturulan otoregresif dağıtılmış gecikmeli modellerin uzun dönem parametresinin ortalamalarını kullanarak uzun dönem parametresi elde eden ve yine heterojen panel veri modellerinden biri olan ortalama grup tahmincisinden (mean group estimator-MG) (Pesaran ve Smith, 1995;Pesaran vd., 1997) farklı olarak, katsayıların havuzlanması ve ortalamalarının bir bileşimidir (Pesaran vd., 1997). MG tahmincisi, parametrelerin ortalamalarının tutarlı tahminlerini ortaya koyabilir. Ayrıca sabit terimlerin, kısa ve uzun dönem katsayılarının ve hata varyanslarının gruplar arasında farklılaşmasına izin vermesine rağmen, belirli parametrelerin gruplar (ülkeler) arasında aynı olabilme durumunu dikkate almaz (Pesaran vd., 1997). Bu eksikliği giderebilen PMG tahmincisinde, tüm yatay kesitler için ortak bir eşbütünleşme denklemi tahmin edilir ve kısa dönem parametreleri ve hata varyanslarının gruplar arasında değişmesine izin vermesine rağmen, uzun dönem parametrelerinin gruplar arasında farklılaşmasına izin vermez, uzun dönem katsayıları tüm gruplar için aynıdır (Pesaran vd., 1997). Bu nedenle bu tahmin ile havuzlanmış uzun dönem katsayıları ve heterojen kısa dönem dinamikleri elde edilir.

Sabit etkiler ile rassal etkiler tahmincisi ya da sabit etkiler tahmincisi ile araç değişken tahmincilerinin bileşimi olan Arellano-Bond GMM tahmincisi gibi geleneksel yöntemler bireysel grupları havuzlamaya ve yalnızca sabit terimlerin farklılaşmasına izin vermektedir. Diğer tüm katsayılar ve hata varyansları gruplar arasında aynidır (Pesaran, Shin ve Smith, 
1999). Ayrıca uzun ve kısa dönem katsayılarının ayrı ayrı hesaplanmasina izin vermemektedir. Yine geleneksel sabit etkiler ve tesadüfi etkiler tahmincileri eğim parametrelerini tüm yatay kesitler için aynı yani homojen olduğunu varsaymaktadır. GMM tahmincileri ayrıca Pesaran vd.,e (1999) göre parametrelerin ortalama değerlerinin tutarsız ve yanıltıcı tahminlerini ortaya koymaktadır. Özetle, PMG tahmincisi havuzlamanın avantajlarını bir araya getirmenin yanı sıra, yeterli heterojenliğe de izin verir ve bu çalışma açısından diğer üstünlükleri ile birlikte en uygun yöntemdir. Adams ve Klobodu (2016) ve Herzer ve Vollmer (2012) tarafından da kullanılmıştır.

PMG ve MG tahmincileri arasındaki seçim Hausman testi yardımı ile yapılır. Bu test uzun dönem katsay1larının homojen olup olmadığını sınar. $\mathrm{H}_{0}$ hipotezi, "uzun dönem katsayıları homojendir" önermesini ve $\mathrm{H}_{1}$ hipotezi, "uzun dönem katsayıları homojen değildir" önermesini sinamaktadır. $\mathrm{H}_{0}$ hipotezi reddedilmemesi, katsayıların yatay kesitten yatay kesite değişmediğini ve PMG tahmincisinin uygun olduğunu söyler.

MG ve PMG tahmincileri, otoregresif dağıtılmış gecikmeli (auto-regressive distributive lag-ARDL) modellere dayanmaktadır. Bağımlı değişken için p gecikme ve bağımsız değişkenler için ortak q gecikmenin olduğu $\operatorname{ARDL}(\mathrm{p}, \mathrm{q}, \mathrm{q}, . ., \mathrm{q})$ modeli denkleminin genel görünümü aşağıdaki gibidir:

$$
y_{i t}=\sum_{j=1}^{p} \lambda_{i j} y_{i, t-j}+\sum_{j=0}^{q} \delta_{i j}^{\prime} x_{i, t-j}+\mu_{i}+\varepsilon_{i t}
$$

6 no'lu denklemde, $i=1,2, \ldots, \mathrm{N}$ grup sayısı, $t=1,2, \ldots, \mathrm{T}$, zaman dönemi, $x_{i t}(\mathrm{k} \times 1)$ i grubu için açıklayıcı değişkenler vektörü, $\delta_{i t} \mathrm{k} \times 1$ boyutunda katsayı vektörleri, $\lambda_{i j}$ gecikmeli bağımlı değişkenlerin katsayıları, $\mu_{i t}$ sabit etkiler, $\varepsilon_{i t}$ ise hata terimidir. Denklem, değişkenlerin kısa dönem dinamiklerinin uzun vadeli ilişkiden sapma tarafından etkilendiği kısıtsız hata düzeltme modeli biçiminde aşağıdaki gibi yeniden yazılabilir:

$$
\begin{aligned}
\Delta \mathcal{Y}_{i t}= & \phi \mathcal{Y}_{i, t-1}+\beta_{i}^{\prime} x_{i t}+\sum_{j=1}^{p-1} \lambda_{i j}^{*} \Delta \mathcal{Y}_{i, t-j}+ \\
& \sum_{j=0}^{q-1} \delta_{i j}^{*} \Delta x_{i, t-j}+\mu_{i}+\varepsilon_{i t}
\end{aligned}
$$

7 no'lu denklemde, $\phi$, uzun döneme doğru ayarlanma hızını ölçen katsayıdır. Sıfırdan farklı ve negatif olma- s1, bağımlı değişken ve açılayııı değişkenler arasında uzun dönemli ilişkinin varlığına işaret eder. uzun dönem katsayıları, açıklayıcı değişkenler vektörüdür.

\section{Kısa ve Uzun Dönem Modellerinin Sonuçları ve Değerlendirme}

Farklı finansal gelişme göstergeleri ile tahmin edilen farklı modellerden elde edilen ortak sonuç finansal gelişmenin gelir eşitsizliğinin artmasına katkıda bulunduğudur. Bu sonuçlar literatürde finansal gelişmenin gelir eşitsizliğini arttırdığını (the inequality-increasing hypothesis) ileri süren hipotezi (Rajan ve Zingales, 2003; Stiglitz, 2012) destekleyici niteliktedir6 .

Tablo 6'da hata düzeltme modelinin, PMG ve MG tahmincisi ile tahmini görülmektedir. PMG tahmincisi ile elde edilen sonuçlara göre, hata düzeltme parametresi negatif ve istatistiksel olarak anlamlıdır. Her ne kadar bu istatistik değerinin anlamlılık derecesi düşük olsa da, modelde kullanılan değişkenler arasında uzun dönemli bir ilişkinin varlığına işaret etmektedir. Hata düzeltme parametresinin değerinin -0.3051 olması, serilerin durağan olmamasından kaynaklanan denge durumundan sapmaların, \%30'unun bir sonraki dönemde düzeleceğini ve sistemin uzun dönem denge durumuna doğru hareket edeceğini ifade etmektedir.

Uzun dönem parametrelerine baktığımızda özel sektöre sağlanan kredilerin GSYH'ya oranında bir artışın, gelir eşitsizliğini arttırdığ 1 görülmektedir. $\mathrm{Bu}$ finansal gelişme göstergesine ait katsayı istatistiksel olarak \%1 düzeyinde anlamlıdır ve özel sektöre sağlanan kredilerde $\% 1$ artışın, gelir eşitsizliğini uzun dönemde \% 0.2762 oranında arttırdığına işaret etmektedir. Finansal gelişme ile gelir eşitsizliği arasındaki ilişkiyi tespit etmeye yönelik bu modelde içselliği kontrol etmek için kullanılan diğer değişkenlerden veya kontrol değişkenlerinden sanayi ve hizmetler sektörü katma değerinin GSYH içerisindeki payının modele göre katsayısının pozitif ve istatistiksel olarak anlamlı olması Kuznets' in (1955) hipotezini destekler niteliktedir ve modern sektörün payında artışın gelir eşitsizliğini arttırdığını göstermektedir. Kontrol değişkeni olarak kullanılan kişi başına düşen reel GSYH

6 Değişkenler arasındaki korelasyonu gösteren Ek Tablo D’de de gini katsayısı ve gelir eşitsizliği göstergeleri arasında pozitif korelasyon da bu hipotezi destekleyici niteliktedir. 
Finansal Gelişsme ve Gelir Eşitsizliği: BRICS Ekonomileri Için Dinamik Heterojen Bir Yaklaşım

Tablo 6. Finansal Gelişmenin Gelir Eşitsizliği Üzerinde Kısa ve Uzun Dönem Etkileri

\begin{tabular}{|c|c|c|}
\hline \multicolumn{3}{|l|}{ Değişkenler } \\
\hline & PMG & MG \\
\hline Ayarlanma Hizl & $-0.3051(0.09)^{*}$ & $-0.6017(0.00)^{* * *}$ \\
\hline \multicolumn{3}{|l|}{ Uzun Dönem } \\
\hline FINDEV $V_{1}$ & $0.2762(0.00)^{* * *}$ & $0.0493(0.64)$ \\
\hline PGDPG & $0.0008(0.32)$ & $-0.0047(0.40)$ \\
\hline HUMANCAP & $-0.0013(0.90)$ & $-0.3368(0.09)^{*}$ \\
\hline MODERN & $0.6985(0.01)^{* * *}$ & $0.9213(0.71)$ \\
\hline \multicolumn{3}{|l|}{ Kısa Dönem } \\
\hline$\Delta$ FINDEV $_{1}$ & $-0.0825(0.19)$ & $-0.1410(0.05)^{* *}$ \\
\hline$\overline{\Delta P G D P G}$ & $0.00009(0.79)$ & $0.0007(0.43)$ \\
\hline$\triangle$ HUMANCAP & $0.3591(0.09)^{*}$ & $-0.1389(0.42)$ \\
\hline$\triangle$ MODERN & $-0.0987(0.77)$ & $0.0537(0.92)$ \\
\hline _cons & $-0.0414(0.06)^{*}$ & $1.8685(0.49)$ \\
\hline Hausman Testi & \multicolumn{2}{|c|}{$6.39(0.17)$} \\
\hline Ülke Sayısı & 5 & 5 \\
\hline Gözlem Sayısı & 109 & 100 \\
\hline Log-Likelihood & 391.8709 & 391.8709 \\
\hline
\end{tabular}

******** sırasılyla \%1, \%5 ve \%10 anlamlllıkları gösterir. ( ) içindeki değerler p değerleridir.

büyüme oranı ve beșeri sermaye endeksinin bu modelde katsayıları istatistiksel olarak anlamlı değildir. MG tahmincisi de aynı sonuçları vermekle birlikte, MG tahmincisinin uzun dönem katsayıları çoğunlukla istatistiksel olarak anlamlı değildir.

Uzun dönem katsayılarının homojen olup olmadığını sinayan ve PMG ve MG tahmincilerinden hangisinin daha uygun bir tahminci olduğu kararını almamıza yarayan Tablo 6'daki Hausman test istatistiği (6.39) istatistiksel olarak anlamlı olmadığından, daha etkin olan PMG tahmincisinin uygun olduğuna karar verilmiştir. Diğer bir ifade ile uzun dönem parametreleri homojendir, ülkeden ülkeye (veya birimden birime) değişmemektedir.

Tablo 7. Finansal Gelişmenin Gelir Eşitsizliği Üzerinde Kısa ve Uzun Dönem Etkileri

\begin{tabular}{|c|c|c|}
\hline Değişkenler & PMG & MG \\
\hline Ayarlanma Hizı & $-0.3836(0.06)^{*}$ & $-0.6433(0.00)^{* * *}$ \\
\hline \multicolumn{3}{|l|}{ Uzun Dönem } \\
\hline FINDEV 2 & $0.3070(0.00)^{* * *}$ & $0.1569(0.19)$ \\
\hline$\overline{\text { PGDPG }}$ & $0.0008(0.19)$ & $-0.0040(0.22)$ \\
\hline HUMANCAP & $-0.0100(0.31)$ & $0.2152(0.15)$ \\
\hline MODERN & $0.0032(0.00)^{* * *}$ & $0.0036(0.64)$ \\
\hline \multicolumn{3}{|l|}{ Kısa Dönem } \\
\hline$\Delta \mathrm{FINDEV}_{2}$ & $-0.1244(0.02)^{* *}$ & $-0.1339(0.14)$ \\
\hline$\overline{\Delta P G D P G}$ & $-0.00008(0.74)$ & $0.0008(0.21)$ \\
\hline$\triangle \mathrm{HUMANCAP}$ & $-0.2297(0.28)$ & $-0.0677(0.79)$ \\
\hline$\triangle$ MODERN & $0.0003(0.80)$ & $-0.001(0.35)$ \\
\hline _cons & $0.5712(0.07)^{*}$ & $0.9384(0.00)^{* * *}$ \\
\hline Hausman Testi & \multicolumn{2}{|c|}{$4.86(0.30)$} \\
\hline Ulke Sayısı & 5 & 5 \\
\hline Gözlem Sayısı & 109 & 109 \\
\hline Log-Likelihood & 390.2929 & 390.2929 \\
\hline
\end{tabular}

***,**,* sırasıyla $\% 1, \% 5$ ve $\% 10$ anlamlllkları gösterir. ( ) içindeki değerler p değerleridir 
Tablo 7’te yine finansal aracılığın gelişimini ölçen ve literatürde sıklıkla kullanılan (Clark, Xu ve Zou, 2006; Adams ve Klobodu, 2016) alternatif bir göstergeden yararlanılmıștır: Mevduat bankaları varlıklarının GSYH'ya oranı. İlk olarak hata düzeltme parametresinin değerine ve anlamlılığına bakılacak olursa, hem PMG hem de MG tahmincisi kullanılarak elde edilen modelde bu parametrenin negatif ve istatistiksel olarak anlamlı olduğu görülmektedir. PMG tahmincisi ile $\quad-0.38$ olarak elde edilen hata düzeltme parametresi, değişkenler arasında uzun dönemli ilişkinin varlığını göstermesinin yanı sıra, denge durumunda meydana gelen sapmaların \%38'inin bir sonraki dönemde düzeleceğini, sistemin uzun dönem dengesine doğru harekete edeceğini göstermektedir.

Tahmin edilen Tablo 7'deki modele göre, uzun dönemde finansal gelişme değişkeninin katsayısı pozitif ve istatistiksel olarak anlamlıdır. Finansal aracilığın gelişmesi veya daha spesifik olarak finansal derinliğin \% 1 oranında artması, gelir eşitsizliğini uzun dö- nemde \% 0.307 oranında arttırmaktadır. Kullanılan kontrol değișkenlerinden yalnızca modern sektörün ekonomideki payını ölçen değişkenin katsayısı istatistiksel olarak anlamlıdır ve gelir eșitsizliğini arttırıcı etki yaratığ 1 tespit edilmiştir. Diğer bir ifade ile ekonominin sektörel yapısında sanayi ve hizmetler sektörüne doğru bir dönüşüm Kuznets'in (1955) de dile getirdiği gibi gelir eşitsizliğini arttırmaktadır. MG tahmincisi ile elde edilen katsayılar istatistiksel olarak anlamlı değildir. PMG ve MG arasında katsayıların homojenliğini test etmek için yapılan Hausman testi de, uzun dönemde katsayıların homojen olduğunu, bu nedenle PMG tahmincisinin uygun bir tahminci olduğunu ortaya koymaktadır.

Tablo 8'de finansal sistemin büyüklüğünün bir ölçüsü olarak likit yükümlülüklerin GSYH'ya oranı, açılayıcı değişken olarak kullanılmış ve gelir eşitsizliği üzerindeki etkisi modellenmiştir. Bu modelde ayarlanma katsayısının değeri yine istatistiksel olarak anlamlı ve negatiftir.

Tablo 8. Finansal Gelişmenin Gelir Eşitsizliği Üzerinde Kısa ve Uzun Dönem Etkileri

\begin{tabular}{|c|c|c|}
\hline Değişkenler & PMG & MG \\
\hline Ayarlanma Hızı & $-0.2021(0.00)^{* * *}$ & $-0.6524(0.00)^{* * *}$ \\
\hline \multicolumn{3}{|l|}{ Uzun Dönem } \\
\hline FINDEV $_{3}$ & $0.1809(0.01)^{* * *}$ & $0.0364(0.87)$ \\
\hline PGDPG & $-0.0051(0.00)^{* * *}$ & $-0.0047(0.62)$ \\
\hline HUMANCAP & $-0.1808(0.00)^{* * *}$ & $-0.2031(0.04)^{* * *}$ \\
\hline MODERN & $1.4273(0.00)^{* * *}$ & $1.1305(0.51)$ \\
\hline \multicolumn{3}{|l|}{ Kısa Dönem } \\
\hline$\Delta$ FINDEV $_{3}$ & $-0.0984(0.45)$ & $-0.1460(0.14)$ \\
\hline$\Delta \mathrm{PGDPG}$ & $0.0009(0.00)^{* * *}$ & $0.0012(0.22)$ \\
\hline$\triangle$ $\triangle$ HUMANCAP & $-0.0755(0.75)$ & $0.0500(0.86)$ \\
\hline$\triangle$ MODERN & $-0.2185(0.58)$ & $-0.1506(0.63)$ \\
\hline _cons & $-0.2009(0.00)^{* * * *}$ & $0.8956(0.62)$ \\
\hline Hausman Testi & \multicolumn{2}{|c|}{$2.74(0.60)$} \\
\hline Ulke Sayısı & 5 & 5 \\
\hline Gözlem Sayısı & 109 & 109 \\
\hline Log-Likelihood & 390.8304 & 390.8304 \\
\hline
\end{tabular}

***,**** sırasıyla $\% 1, \% 5$ ve \%10 anlamlllıkları gösterir. ( ) içindeki değerler p değerleridir

Bu modele göre, ilk iki model gibi finansal gelişmenin uzun dönemde gelir eșitsizliğini arttırdı ğı, finansal gelișmenin bir göstergesi olan likit yükümlülüklerin GSYH'ya oranında \%1 artışın, gelir eşitsizliğini \% 0.18 oranında arttırdığ 1 tespit edilmiştir. Kişi başına düşen gelirin büyüme oranının katsayısının, literatür ile uyumlu biçimde (Beck, Demirgüç-Kunt ve Levine, 2007;Ang, 2010) negatif ve istatistiksel olarak anlaml olması, kiși başına düșen gelirdeki büyümenin gelir eşitsizliğini azalttığını ortaya koymaktadır. Beşeri sermaye endeksinin katsayısının da literatür ve beklentilerle uyumlu bir biçimde eşitsizliği azalttığı gö- 
rülmektedir (Law, Tan ve Azman-Saini, 2014). Sanayi ve hizmetler sektörünün ekonomideki payının artması Tablo 8'deki model sonuçlarına göre Kuznets'in (1955) hipotezini destekler biçimde gelir eşitsizliğini arttırmaktadır. Yine diğer modellerde olduğu gibi katsayıların homojenliği hakkında karar almaya yarayan Hausman katsayısının değeri 2.74'tür ve istatistiksel olarak anlamlı değildir. Bu da PMG tahmincisinin daha etkin bir tahminci olduğunu ortaya koymaktadır.

\section{Sonuç}

Finans sektörünün hem ekonomiye hem de genel olarak topluma katkısı son yıllarda yoğun bir biçimde tartışılmaktadır. Özellikle 2008-2009 Global Finans krizinin ardından bu sektörün gelir eşitsizliği üzerindeki etkisi daha fazla sorgulanmaya başlamıştır. Hem teorik yaklaşımların, hem de ampirik çalıșmaların görüş birliği sağlayamaması, literatürde finansal gelişme-gelir eşitsizliği ilişkisini inceleyen çalışmaların arttırılmasını gerektirmektedir.

Bu çalışmada ABD kapitalizmi veya Anglo-Sakson kapitalizmi karşısına ciddi bir rakip olarak çıkan, daha heterodoks politikalarla GSYH, ticaret ve sanayi katma değerindeki büyüme açısından $\mathrm{ABD}, \mathrm{AB}$ ülkeleri ve Japonya gibi yerleşik ekonomileri geride bırakmayı başararak (May ve Nölke, 2014) küresel büyümenin öncüsü haline gelen ve "stratejik kapitalizm", "yeni devlet kapitalizmi” gibi isimler adı altında mukayeseli politik ekonomi içerisinde kendisine yer edinen BRICS ekonomilerinde finansal gelişmenin gelir eşitsizliği üzerindeki etkisi araştırılmıştır. $\mathrm{Bu}$ ekonomilerde daha kontrollü finans sektörü, iktisadi büyümeye aracilık etse de (Pradhan, Dasgupta ve Bele, 2013), firsat eşitliği yaratarak toplumun tüm kesimlerini aynı ölçüde etkileyip etkilemediği konusu literatürde incelenmesi gereken alanlardan birisidir. $\mathrm{Bu}$ nedenle bu çalışmada, 1990-2014 döneminde BRICS ekonomilerinde, finansal gelişme-gelir eşitsizliği ilişkisi araştırılmıştır. İhmal edilen değişkenlerin yarattığı sapma, içsellik ve ülke heterojenliği sorunu ile başa çıkabilen ve uzun ve kısa dönem parametrelerini ayrı ayrı hesaplanması gibi klasik yöntemlere nazaran üstünlükleri olan PMG tahmincisi kullanılarak bu literatüre katkıda bulunulmuştur.

PMG tahmincisi ile doğrusal bir model tahmin elde edilerek elde edilen sonuçlar literatürde finansal ge- lişmenin gelir eşitsizliğini arttırdığını ileri süren hipotezi destekler niteliktedir. Diğer bir ifade ile elde edilen sonuçlar finansal gelişmenin gelir eşitsizliğini arttırdığına işaret etmektedir. Bu sonuç, Stiglitz (2012) ile Rajan ve Zingales'in (2003) görüşlerini destekler niteliktedir. Ayrıca bu konuda Sehrawat ve Giri (2015), Seven ve Coşkun (2016) ile Adams ve Klobo$\mathrm{du}$ (2016) tarafindan yapılan ampirik analizlerin sonuçları ile de uyumludur. Bununla birlikte ekonomide modern sektör lehine bir değişmenin, Kuznets'in (1955) görüşlerini destekler biçimde gelir eşitsizliğini arttırdığı, ancak kişi başına düşen GSYH büyüme oranındaki artış ile beşeri sermayedeki artışın gelir eşitsizliğini azalttığı tespit edilmiştir.

Ampirik sonuçların finansal gelişmenin gelir eşitsizliğini arttırdığını ortaya koyması, finans sektöründeki gelişmelerden toplumun tüm kesimlerinin yararlanmasını sağlayıcı önlemlerin alınması gerektiğini ve finansal erişimin (financial inclusion) önemini ortaya koymaktadır. Ayrıca gelişmekte olan ülkelerde, daha gelişmiş bir kurumsal altyapı önemli bir zorunluluktur. Finans sektörünün toplumun tüm kesimlerine kaynak sağlaması, ülkelerdeki kural ve kurumların şeffaf ve herkes için eşit olmasına bağlıdır. Böylelikle kredi ve varlık piyasasındaki gelişmelerden yetenekli ancak düşük gelirli bireyler de faydalanabilecek, diğer bir ifade ile fırsat eşitliği sağlanmış olacaktır. Kurum ve kuralların yetersiz oluşu, firsat eşitliğinin bozulmasına, piyasanın daha kırılgan ve kaygan bir zemine oturmasina neden olacaktır.

\section{Kaynakça}

Adams, S., Klobodu, E.K.M. (2016). Financial Development, Control of Corruption and Income Inequality. International Review of Applied Economics, 30(6), 790-808.

Acemoğlu, D., Robinson, J. A. (2015). The Rise and Decline of General Laws of Capitalism. Journal of Economic Perspectives, 29(1), 3-28.

Ang, J. B. (2010). Finance and Inequality: The Case of India. Southern Economic Journal, 76(3), 738-761.

Aghion, P., Bolton, P. (1997). A Theory of TrickleDown Growth and Development. The Review of Economic Studies, 64(2), 151-172. 
Baltagi, B. H. (2005). Econometric Analysis of Panel Data. Third Edition, John Wiley \&Sons: Chichester, England.

Banerjee, A.V., Newman, A. F. (1993). Occupational Choice and the Process of Development. Journal of Political Economy 101 (2), 274-298.

Bank of Russia (BOR) (2016) Guidelines for The Development of the Russian Financial Market in 20162018. https://www.cbr.ru/StaticHtml/File/12098/ onrfr_2016-18_e.pdf.

Beck, T., Demirgüç-Kunt, A., Levine, R. (2007). Finance, Inequality and the Poor. Journal of Economic Growth, 12, 27-49.

Bittencourt, M. F. (2006). Financial Development: Brazil 1985-1999. Discussion Paper, No. 06/582, 1-24. https://econrsa.org/papers/w_papers/wp86.pdf.

Batuo, M. E., Guidi, F., Mlambo, K. (2010). Financial Development and Income Inequality: Evidence from African Countries, MPRA Paper, No.25658. https://mpra.ub.uni-muenchen.de/25658/1/ MPRA_paper_25658.pdf.

Breitung, J. (2001). The Local Power of Some Unit Root Tests for Panel Data. Badi Baltagi, Thomas B. Fomby, R. Carter Hill (Ed.), Nonstationary Panels, Panel Cointegration, and Dynamic Panels (Advances in Econometrics), in (Vol. 15, pp. 161-178). UK: Emerald Group Publishing Limited.

Chittedi, K. R. (2009). Global Stock Markets Development and Integration: With Special Reference to BRIC Countries. MPRA Paper, No. 18602, 1-20. https://mpra.ub.uni-muenchen.de/18602/1/ MPRA_paper_18602.pdf.

Claessens, S., Perotti, E. (2007). Finance and Inequality: Channels and Evidence. Journal of Comparative Economics 35, 748-773.

Clarke, G., Xu, L. C., Zou, H. (2006). Finance and Income Inequality: What do the Data Tell Us?. Southern Economic Journal, 72:578-96.
Feng, E. (2011). The End of Growth With Equity? Economic Growth And Income Inequality In East Asia. Asia Pacific Issues, East-West Center, No. 101, 1-8. https://www.brookings.edu/articles/theend-of-growth-with-equity-economic-growthand-income-inequality-in-east-asia/.

Galor, O., Zeira, J. (1993). Income Distribution and Macroeconomics. Review of Economic Studies, 60 (1), 35-52.

Greenwood, J., Jovanovic, B. (1990). Financial Development, Growth, and the Distribution of Income. Journal of Political Economy, 90 (5), 1076-1107.

Hamori, S., Hashiguchi, Y. (2012). The Effect of Financial Deepening on Inequality: Some International Evidence. Journal of Asian Economics, 23, 353-359.

Herzer, D., Vollmer, S. (2012). Inequality and Growth: Evidence from Panel Cointegration. Journal of Economic Inequality 10 (4): 489-503.

Hodgson, G. M. (2015). Conceptualizing Capitalism: Institutions, Evolution, Future. London: The University of Chicago Press.

Im, K. S., Pesaran, M. H., Shin, Y. (2003). Testing for Unit Roots in Heterogeneous Panels. Journal of Econometrics, 115, 1, 53-74.

Jauch, S., Watzka, S. (2016). Financial Development and Income Inequality: A Panel Data Approach. Empirical Economics, 51(1), 291-314.

Kao, C. (1999). Spurious Regression and Residual-Based Tests for Cointegration in Panel Data. Journal of Econometrics, 25: 54-77.

Kim, D., Lin, S., (2011). Nonlinearity in the Financial Development-Income Inequality Nexus. Journal of Comparative Economics, 39 (3), 310-325.

Kuznets, S. (1955). Economic Growth and Income Inequality. American Economic Review, 45 (1), 1-28. 
Law, S. H., Tan, H.B., Azman-Saini, W.N.W, (2014). Financial Development and Income Inequality at Different Levels of Institutional Quality. Journal Emerging Markets Finance and Trade, 50 (1), 2133.

Levine, R., Loayza, N., Beck, T. (2000). Financial Intermediation and Growth: Causality and Causes. Journal of Monetary Economics, 46, 31-77.

Liang, Z. (2006). Financial Development and Income Distribution: A System GMM Panel Analysis with Application to Urban China. Journal of Economic Development, 34 (2), 1-21.

Ljungqvist, L. (1993). Economic Underdevelopment: The Case of a Missing Market for Human Capital. Journal of Development Economics, 40, 219-239.

Maddala, G.S., Wu, S. (1999). A Comparative Study of Unit Root Tests with Panel Data and a New Simple Test. Oxford Bulletin of Economics and Statistics. 61 (S1), special issue, 631- 652.

May, C., Nölke, A. (2014). Capitalism in Large Emerging Economies and the New Global Trade Order. David Desse (ed.) Handbook of the International Political Economy of Trade. Cheltenham: Edward Elgar.

McNally, C. A. (2013a). The Challenge of Refurbished State Capitalism: Implications for the Global Political Economic Order. Recht and Management, 6, 33-48. http://www.budrich-journals.de/index.php/ dms/article/view/13109/11407.

McNally, C.A. (2013b). How Emerging Forms of Capitalism Are Changing the Global Economic Order. East-West Center, No.107, 1-8. https://www.eastwestcenter.org/sites/default/files/private/api107. pdf.

Mensi, W., Hammoudeh, S., Reboredo J. C., Nguyen, D. K. (2014). Do Global Factors Impact BRICS Stock Markets? A Quantile Regression Approach, Emerging Markets Review, 19, 1-17.
Novokmet, F., Piketty, T., Zucman G. (2017). From Soviets to Oligarchs: Inequality and Property in Russia 1905-2016. World Working Paper Series, No. 2017/09. http://piketty.pse.ens.fr/files/ NPZ2017WIDworld.pdf.

Nölke, A., Claar, S. (2013). Varieties of Capitalism in Emerging Countries. Transformation, 81/82, 3354.

Nölke, A., Vliegenthart, A. (2009). Enlarging the Varieties of Capitalism: The Emergence of Dependent Market Economies is East Central Europe. World Politics, 61(4), 670-702.

O’ Neill, J. (2001). Building Better Global Economic BRICS. Goldman Sachs: http://www.goldmansachs.com/our-thinking/ archive/archive-pdfs/ brics-book/brics-full-book.pdf.

Pedroni, P. (1999). Critical Values for Cointegration Tests in Heterogeneous Panels with Multiple Regressors. Oxford Bulletin of Economics and Statistics, 61 (Special Issue), 653-670.

Pedroni, P. (2004). Panel Cointegration: Asymptotic and Finite Sample Properties of Pooled Time Series Tests with Application to the PPP Hypothesis. Econometric Theory, 20(3), 597-625.

Pesaran, M. H., Smith, R.P. (1995). Estimating Longrun Relationships From Dynamic Heterogeneous Panels. Journal of Econometrics, 68 (1): 79-113.

Pesaran, M. H., Shin, Y., Smith, R.P. (1997). Pooled Estimation of Long-Run Relationships in Dynamic Heterogeneous Panels: University of Cambridge, Department of Applied Economics.

Pesaran, M. H., Shin, Y., Smith, R.P. (1999) Pooled Mean Group Estimation of Dynamic Heterogeneous Panels. Journal of the American Statistical Association, 94 (446): 621-634. 
Pradhan, R. P., Dasgupta, P., Bele, S. (2013). Finance, Development and Economic Growth in BRICS: A Panel Data Analysis. Journal of Quantitative Economics, 11, (1\&2), 308-322.

Prasad, E. S. (2016). China`s Economy and Financial Markets: Reforms and Markets, U.S-China Economic and Security Review Commission, Hearing on China's $13^{\text {th }}$ Five Year Plan, 1-16. https://www. brookings.edu/wp-content/uploads/2016/07/USCESRCTestimony27Apr16.pdf.

Rajan, R. G., Zingales, L. (2003). Saving Capitalism From The Capitalist. New Jersey: Princeton University Press.

Schultz, T. W. (1961). Investment in Human Capital. The American Economic Review, 51 (1), 1. 1-17.

Sehrawat, M., Giri, A. (2015). Financial Development and Income Inequality in India: An Application of ARDL Approach. International Journal of Social Economics, 42 (1), 64-81.

Shah, A., Patnaik, I. (2011), India’s Financial Globalisation, IMF Working Paper, WP/11/7. https://www. imf.org/en/Publications/WP/Issues/2016/12/31/ India-s-Financial-Globalisation-24558.
Solt, F. (2016). The Standardized World Income Inequality Database. Social Sciences Quarterly. 97(5) Issue, 1267-1281.

Stiglitz, J. E. (2012). The Price of Inequality: How Today's Divided Society Endangers Our Future. USA:W.W. Norton\&Company Inc.

Şenses, F., Öniş Z., Bakır, C. (2013). Ülke Deneyimleri Işığında Küresel Kriz ve Yeni Ekonomik Düzen. İstanbul: İletişim Yayınları.

Ünay, S., Kayıkçı, F. (2013). Çok Kutuplu Küresel Ekonomik Düzen ve BRICS: Kriz Sonrası Sistematik Dönüşüm. Fikret Şenses, Ziya Öniş Ziya, Caner Bakır (Ed.). Ülke Deneyimleri Işığında Küresel Kriz ve Yeni Ekonomik Düzen, içinde (s.259-283). İstanbul: İletişim Yayınları.

Wiltse, E.Ç. (2013). Küresel Ekonomik Kriz Sonrasında Yeni Dünya Düzeni: 2008 Krizi, Brezilya ve Yeni Sosyal Demokrat Kalkınmacı Model Tartışmaları. Fikret Şenses, Ziya Öniş Ziya, Caner Bakır (Ed.). Ülke Deneyimleri Işığında Küresel Kriz ve Yeni Ekonomik Düzen, içinde (s.311-333), İstanbul: İletişim Yayınları. 
Ek Tablo A. Yatırımların Finansmanı ${ }^{7}$ (2015)

\begin{tabular}{|l|c|c|c|}
\hline & $\begin{array}{c}\text { Mevduat Bankaları ile Diğer } \\
\text { Finansal Kurumların Özel } \\
\text { Sektöre Sağladığı Toplam } \\
\text { Kredi Hacminin GSYH'ye } \\
\text { Oranı (\%) }\end{array}$ & $\begin{array}{c}\text { Sermaye Piyasasında İşlem } \\
\text { Yapan Firmaların Piyasa } \\
\text { Değerlerinin Toplamının } \\
\text { GSYH'ye Oranı (\%) }\end{array}$ & $\begin{array}{c}\text { Doğrudan Yabancı Yatırım } \\
\text { Stoku/GSYH (\%) }\end{array}$ \\
\hline Brezilya & $\mathbf{7 1 . 2 6}$ & $\mathbf{3 1 . 1 1}$ & $\mathbf{2 6 . 0}$ \\
\hline Çin & $\mathbf{1 4 0 . 4 0}$ & $\mathbf{6 4 . 1 4}$ & $\mathbf{2 2 . 9}$ \\
\hline Hindistan & $\mathbf{5 0 . 2 5}$ & $\mathbf{7 1 . 5 0}$ & $\mathbf{4 0 . 3}$ \\
\hline Güney Afrika & $\mathbf{1 4 6 . 2 3}$ & $\mathbf{2 4 5 . 7 2}$ & $\mathbf{1 9 . 2}$ \\
\hline Rusya & $\mathbf{5 5 . 8 9}$ & $\mathbf{2 4 . 1 4}$ & 23.4 \\
\hline Almanya & 77.52 & 47.12 & 47.8 \\
\hline Avusturya & 85.83 & 23.42 & 30.9 \\
\hline ABD & 179.65 & 143.31 & 49.2 \\
\hline Ingiltere & 134.69 & 112.11 & \\
\hline
\end{tabular}

Kaynak: UNCTAD, Dünya Bankası Finansal Yapı Veritabanı

\section{Ek Tablo B. BRICS Ekonomilerinde Gelir Eşitsizliği Profili (Gini Katsayısı)}

\begin{tabular}{|l|c|c|c|c|}
\hline & Ortalama & Standart Sapma & Minimum & Maksimum \\
\hline Brezilya & 49.34 & 2.28 & 45.00 & 52.49 \\
\hline Çin & 44.90 & 5.99 & 34.89 & 51.51 \\
\hline Hindistan & 45.36 & 2.03 & 42.72 & 48.34 \\
\hline Rusya & 36.50 & 4.19 & 23.60 & 44.77 \\
\hline Güney Afrika & 57.12 & 1.45 & 54.94 & 59.65 \\
\hline
\end{tabular}

Kaynak: Standartlaştırılmış Dünya Gelir Eşitsizliği Veritabanı (The Standardized World Income Inequality Database (SWIID)).

Ek Tablo C. Yatay Kesit Bağımsızlık Testi (Pesaran $C_{L M}$ Test)

\begin{tabular}{|l|c|c|c|}
\hline & $\begin{array}{c}F I N D E V_{1} \text { ile tahmin edilen } \\
\text { model }\end{array}$ & $\begin{array}{c}\text { FINDEV } \\
\text { ile tahmin edilen } \\
\text { model }\end{array}$ & $\begin{array}{c}\text { FINDEV } \\
\text { ile tahmin edilen } \\
\text { model }\end{array}$ \\
\hline Sabit Etki & $-2.433(1.98)$ & $-2.470(1.98)$ & $-2.806(1.99)$ \\
\hline
\end{tabular}

***,**,* strastyla \%1, \%5 ve \%10 anlamlilikları gösterir.

Not: Yatay kesitlerin hata terimleri arasında korelasyonun varlığını sınamak için yapılmış olan Pesaran $\mathrm{CD}_{\mathrm{LM}}$ testi sonuçlarına göre yatay kesitlerin hata terimleri arasında korelasyon yoktur.

\section{Ek Tablo D. Korelasyon Matrisi}

\begin{tabular}{|l|c|c|c|c|c|c|c|}
\hline & $(1)$ & $(2)$ & $(3)$ & $(4)$ & $(5)$ & $(6)$ & (7) \\
\hline (1) GINI & 1.00 & & & & & & \\
\hline (2) FINDEV $_{1}$ & 0.33 & 1.00 & & & & & \\
\hline (3) FINDEV $_{2}$ FINDEV $_{3}$ & 0.40 & 0.95 & 1.00 & & & & \\
\hline (4) & 0.13 & 0.84 & 0.86 & 1.00 & & & \\
\hline (5) PGDPG & -0.01 & 0.43 & 0.40 & 0.58 & 1.00 & & \\
\hline (6) HUMANCAP & -0.48 & -0.18 & -0.22 & -0.25 & -0.11 & 1.00 & \\
\hline (7) MODERN & 0.26 & 0.08 & 0.10 & -0.22 & -0.29 & 0.58 & 1.00 \\
\hline
\end{tabular}

7 BRICS ekonomilerinde yatırımların finansman kaynakları, Nölke ve Vliegenthart’ın (2009) Doğu Avrupa'da bağımlı piyasa ekonomilerini tasvir ettikleri tabloda kullandıkları göstergeler temel alınarak oluşturulmuştur.

8 İngiltere'de Sermaye Piyasasında İşlem Yapan Firmaların Piyasa Değerlerinin Toplamının GSYH'ye Oranına (\%) ait veriler 2012 yılından sonra elde edilemediğinden, 2012 yılına ait veri kullanılmıştır 